\title{
Three thousand year paleo-tsunami history of the southern part of the Japan Trench
}

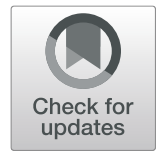

\author{
${\text { Hokuto Higaki }{ }^{*} \text { (D), Kazuhisa Goto }}^{2,3}$, Hideaki Yanagisawa ${ }^{4}$, Daisuke Sugawara ${ }^{2,5}$ and Takashi Ishizawa ${ }^{2}$
}

\begin{abstract}
This study conducted a field survey and multiproxy analyses on sediment cores retrieved from the Kobatake-ike pond in Choshi City, Chiba Prefecture, Japan. Kobatake-ike pond is located at a high elevation (i.e., $11 \mathrm{~m}$ above present-day sea level) and faces the southern part of the Japan Trench. Three event sand layers were detected within the continuous mud and peat sequences of 3000 years. Based on the multi-proxy analyses, including mineralogical composition, diatom assemblages, and geochemical markers, these sedimentological events were associated with past tsunamis. The most recent event was a sandy layer and is attributed to the AD 1677 Enpo tsunami, which was reported by an earlier study conducted in the pond. Our results demonstrated that two older sand layers are associated with large tsunamis that struck the Choshi area in AD 896-1445 and in BC 488-AD 215. In addition, the age ranges of these events seem to overlap that of large earthquakes and tsunamis known from the central part of the Japan Trench. This implies a possible spatiotemporal relation of earthquake generations between the central and southern parts of the Japan Trench. However, since the error ranges of the ages of tsunami deposits at the southern and central parts of the Japan Trench are still large, further investigation is required to clarify the relations of large earthquakes in both areas.
\end{abstract}

Keywords: Tsunami deposit, Radiocarbon dating, ITRAX, Southern Japan Trench

\section{Introduction}

The Tohoku-oki earthquake and tsunami on March 11, 2011 caused severe damage to the Pacific coast from Tohoku to the Kanto region (Toda 2012). Seismological studies by Simons et al. (2011) and Toda et al. (2011) reported that the strain balance has changed in the southern part of the Japan Trench due to the earthquake. The studies also indicated the possibility of an increase in the risk of future occurrence of large earthquakes in this region. Therefore, historical records and tsunami deposits need to be investigated to understand the recurrence interval and magnitudes of large earthquakes in this region and risk assessment.

Tsunami deposits are useful for identifying tsunami events with more extended time scales, i.e., more than hundreds of years. Therefore, they are effective for detecting huge tsunami events with prolonged recurrence

\footnotetext{
* Correspondence: hokuto.higaki.p2@dc.tohoku.ac.jp

${ }^{1}$ Department of Earth Sciences, Graduate School of Science, Tohoku

University, Sendai 980-8578, Japan

Full list of author information is available at the end of the article
}

intervals (Goto et al. 2021; Sawai 2012, 2020; Sugawara et al. 2012). Due to the Tohoku-oki earthquake and tsunami in 2011, considerable effort by scientific communities has been dedicated to elucidating paleo-tsunami events using tsunami deposits. Moreover, the findings from the analyses of the deposits have been critical for the long-term risk assessment of huge tsunami events. Since the occurrence of Tohoku-oki event in 2011, many studies have been conducted along the coasts facing the central to northern parts of the Japan Trench to reevaluate paleo-tsunami histories (e.g., Goto et al. 2015, 2019; Inoue et al. 2017; Ishimura and Miyauchi 2015; Ishizawa et al. 2018, 2019; Kusumoto et al. 2018; Minoura et al. 2013; Sawai et al. 2012, 2015; Takada et al. 2016; Takeda et al. 2018; Tanigawa et al. 2014a, 2014b; Watanabe et al. 2014; see also Sawai 2017, 2020). For instance, Tanigawa et al. (2014b) reported two event layers of the past 6000 years in a meadow of Misawa City, Shimokita Peninsula, Aomori Prefecture (Fig. 1). The recurrence interval of the massive tsunamis in the Sanriku region was estimated to be 290-390 years (Ishimura and 


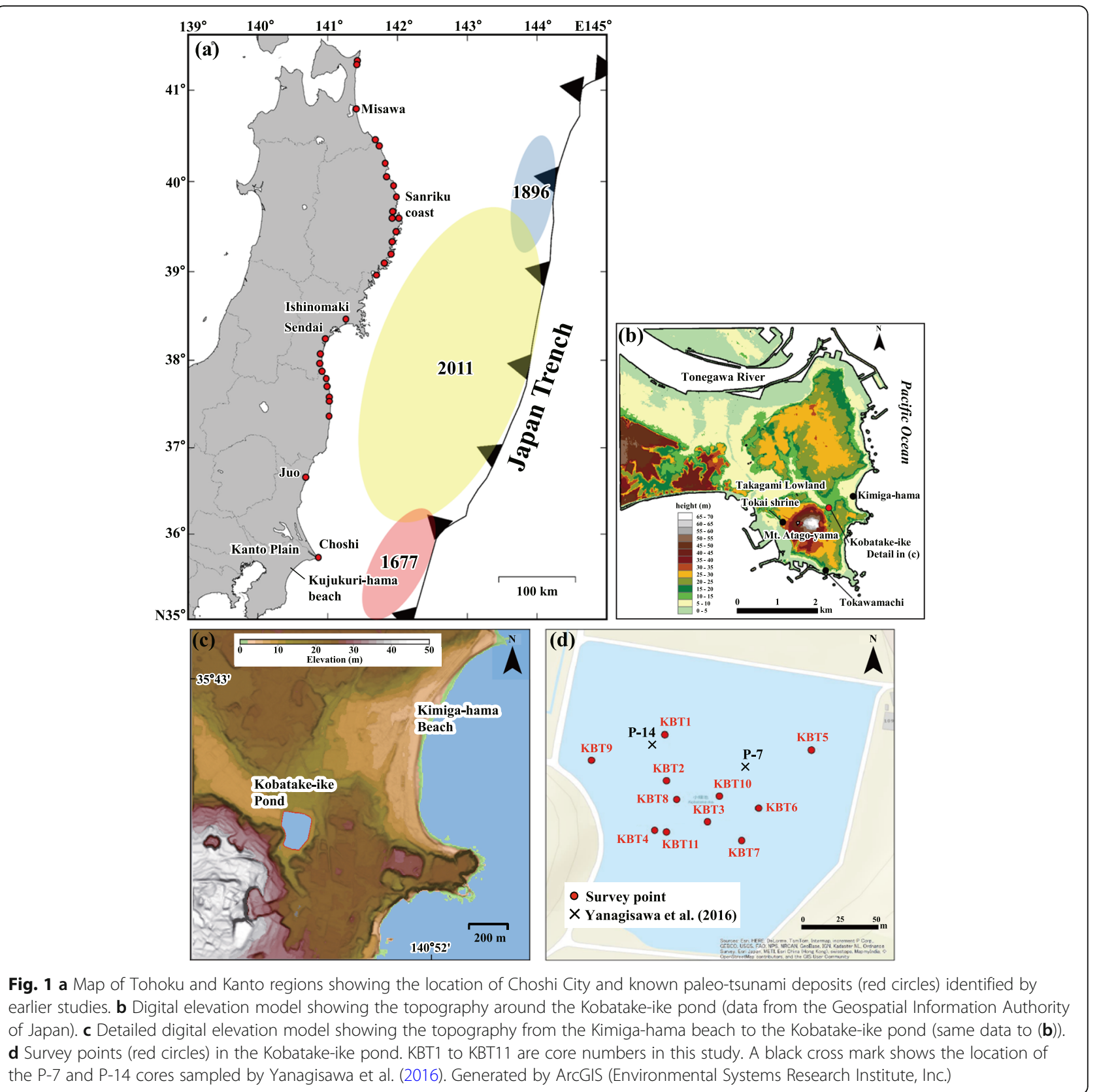

Miyauchi 2015), 500-750 years (Takada et al. 2016), or 400-600 years (Inoue et al. 2017). Around the Sendai and Ishinomaki Plains, near the central part of the Japan Trench, the paleo-tsunami history for the past 3000 years was obtained, including historically well-known tsunamis, i.e., the 869 Jogan, the 1611 Keicho, and possibly the 1454 Kyotoku tsunamis (Sawai et al. 2012). Others (Matsumoto et al. 2013) have reported a prehistoric tsunami occurrence approximately 2000 years ago in the Sendai and Ishinomaki Plains.

In contrast, known historical and prehistoric tsunami deposits in the coasts facing the southern part of the Japan Trench (i.e., Ibaraki to Chiba Prefectures) are limited because of the modern urbanization in the coastal regions. Sawai et al. (2012) reported three event layers from approximately 1000 years ago at northern Ibaraki in Juo Town (Fig. 1a, Sawai et al. 2012). Yanagisawa et al. (2016) identified the deposits formed by the 1677 Enpo Boso-oki earthquaketsunami ( $\mathrm{Mw}$ 8.34-8.63) from historical and geological studies at the Kobatake-ike pond in Choshi City (Fig. 1a). To date, there is no unified explanation of paleo-tsunami history in the southern part of the Japan Trench. 
Historical records show that large tsunamigenic earthquakes occurred previously in the southern part of the Japan Trench. One such event is the Enpo Boso-oki earthquake and tsunami in 1677, which affected an area extending over $600 \mathrm{~km}$ in Choshi City, with a maximum run-up height of approximately $13 \mathrm{~m}$ (Hatori 2003; Takeuchi et al. 2007; Tsuji et al. 2012). Although no predecessor of this event is known, a local tradition at the Tokai Shrine in the city (Fig. 1b) indicates that the shrine was affected by a tsunami occurring around AD 976, after which the shrine was relocated from Hiyoriyama in Tokawamachi (Fig. 1) to the Takagami area (Choshi Geopark Promotion Council 2016). The tsunami-related relocation time is based on a local traditional knowledge rather than written records; therefore, its reliability is likely lower than other historical tsunamis (e.g., 1677 Enpo Boso-oki tsunami).

The Kobatake-ike pond is a good site for paleotsunami research in this region, considering the discovery of the deposits from the 1677 Enpo Boso-oki tsunami. Coastal lakes and marshes are regarded as suitable locations for paleo-tsunami research because the sediments are not disturbed by human activities, even in urbanized areas (Sawai 2012). The Kobatake-ike pond is one such coastal lake located at high elevation (Fig. 1b), thus offering prospects for estimating massive tsunamis' histories and magnitudes. Furthermore, the local traditional knowledge regarding the possible AD 976 event also exists. In this study, a geological survey and sedimentological and geochemical analyses of sediments retrieved from the Kobatake-ike pond were conducted to elucidate the paleo-tsunami history in the southern part of the Japan Trench.

\section{Study area}

Choshi Peninsula, which includes the Kobatake-ike pond, is located at the Kanto Plain's eastern edge (Fig. 1a). The late Pleistocene marine terraces consisting of upper and lower Shimousa surfaces are distributed in the southern part of the peninsula and surround Mt. Atago-yama, where a Mesozoic formation is exposed (Kashima 1985). The Kobatake-ike pond is located at the valley plain, called the Takagami lowland, which developed along these terraces (Fig. 1b). The Takagami lowland is approximately $500 \mathrm{~m}$ wide and $3 \mathrm{~km}$ long, with a sharply bent shape (Kashima 1985). The eastern margin of the lowland is closed by beach ridges. Ota et al. (1985) report that the Takagami lowland had emerged above sea level by approximately $5000 \mathrm{yr}$ BP and marine terraces were formed. Subsequently, the Takagami lowland continued to rise to its present elevation. The average uplift rate is estimated to be approximately $0.4 \mathrm{~m} / \mathrm{kyr}$ (Ota et al. 1985). Based on the diatom analysis results, Kashima et al. (1990) showed that the marine transgression started at 10,000 yr BP.
They also reported that the sea level in the Takagami lowland likely reached almost present-day levels at about 7000 yr BP and temporary desalination may have occurred at 7000-6000 yr BP. At approximately $3000 \mathrm{yr}$ BP, the desalination across the Takagami lowland, was complete. Since then, no evidence of transgression has been confirmed (Kashima 1985).

The Kobatake-ike pond in Choshi City is located 500 $\mathrm{m}$ inland from the shoreline at a high elevation (T.P. 11 $\mathrm{m}$, Fig. 1b). Furthermore, 13-20 $\mathrm{m}$ high beach ridges comprise the eastern side of the coast. No historical or instrumental records indicate that the pond was inundated by storm surges and waves over the last 400 years, except for the 1677 event. Hence, neither storm waves nor small- and medium-scale tsunamis might have inundated the pond (Yanagisawa et al. 2016). Therefore, evidence of seawater invasion in the pond directly indicates the occurrence of a past large tsunami similar to the AD 1677 event.

The pond does not receive major river input and the pond water is supplied by a spring of Mt. Atago-yama, located southwest of the pond. This pond is a freshwater environment used as an agricultural reservoir with an area of $0.03 \mathrm{~m}^{2}$ and average water depth of $0.5 \mathrm{~m}$. The present pond's outer rim is covered by reeds. There is no high cliff around the Kobatake-ike pond that supplies sand into the pond (Fig. 1c). Kashima et al. (1990) reported that the Takagami lowland is covered by 0 to $5 \mathrm{~m}$ thick peat, which has been accumulated since ca. $5000 \mathrm{yr}$ BP.

Yanagisawa et al. (2016) identified two sand layers from cores collected from the pond. The upper sand layer was identified as the AD 1677 Enpo tsunami deposit; meanwhile the origin and age of the lower sand layer have been uncertain. Based on tsunami numerical simulations, they demonstrated that the magnitude of the AD 1677 earthquake can be estimated at Mw 8.348.63. Their simulation suggested that the rupture zone of the 1677 earthquake is located near the trench axis, which is similar to the AD 1896 Sanriku earthquake (Mw 8.3-8.6) that occurred along the northern Japan Trench (Fig. 1a).

\section{Samples and methods}

\subsection{Field survey}

In August 2016, 11 sediment cores were obtained from the pond floor (Fig. 1d). To retrieve the cores, a $100 \mathrm{~cm}$ long Russian peat sampler (Jowsey 1966) was used. After measuring the water depth, we obtained the first core at a depth of $100 \mathrm{~cm}$ from the pond surface. Cores were obtained side-by-side with at least $20 \mathrm{~cm}$ overlap in depth to guarantee lithostratigraphic correlation. Then, we obtained samples reaching up to $400 \mathrm{~cm}$ depth at each point to produce a composite lithostratigraphic section. We used the core P-14, which was the longest core 
among all cores obtained from the Kobatake-ike pond and taken by Yanagisawa et al. (2016), for radiocarbon dating, diatom analysis, and geochemical measurements.

\subsection{Laboratory analyses}

The upper and lower boundaries of the event deposits are sometimes unclear to visual observations (e.g., Bondevik et al. 1997). To ascertain appropriate boundaries, we adopted X-ray computed tomography (CT) scanning, the brightness of which reflects the density or changes in the chemical composition of the sample (Boespflug et al. 1995). The application of CT scanning to tsunami deposits helps to understand characteristics such as grain size distribution and sedimentary structures in a non-destructive way (e.g., Cuven et al. 2013; Falvard et al. 2018; Falvard and Paris 2017). We used CT scanning for all core samples that we obtained and the P-14 core. Then, we defined the sand layer thickness. Analyses were performed using a CT scanner (LightSpeed Ultra 16; GE Healthcare Japan Company, and Aquilion NEW PRIME; Toshiba Medical Systems Corp.) at the Center for Advanced Marine Core Research at Kochi University.

To identify the sand source, we examined the mineralogical composition of the sands in the event deposits. Samples from the event deposits in the Kobatake-ike pond and the beach sand at Kimiga-hama (Fig. 1b) were used for examination. Before this analysis, $10 \%$ hydrogen peroxide was added to remove organic material, and the mud component was removed using a $63 \mu \mathrm{m}$ sieve. Then, the samples were dried and observed using a stereo microscope.

Grain size analysis was performed to investigate the grading trend of the representative event deposit. Sediments were sampled at $1 \mathrm{~cm}$ vertical intervals and cut into halves to use analyses of grain size and sand content. Mud components were removed using $63 \mu \mathrm{m}$ sieve. The samples were dried and then $10 \%$ hydrogen peroxide was added to remove organic material. Subsequently, they were immersed in a dispersion solution $(0.01 \mathrm{~mol} / \mathrm{L}$ aqueous solution of sodium diphosphate) and stirred to disperse mud particles. Grain size was then measured using a laser granulometer (SALD-2300; Shimadzu Corp.). The results are shown as the volume percentage of the grain size distribution.

Diatom assemblages were investigated to estimate the source of the event deposits. The presumed 1677 Enpo tsunami deposit had already been studied by Yanagisawa et al. (2016), which reported the presence of marine diatoms. Therefore, we focused on the analysis of older two event deposits. Samples were basically collected at equal intervals above and below the event deposits. In addition, when the boundary of the event deposit was unclear, an additional sample was retrieved. Then, diatom analysis was commissioned to Paleo Labo Co., Ltd., Japan. Each sample was observed under a microscope at a magnification of 600 to 1000. More than 200 diatom fossils were identified and counted. Diatom tests were categorized into four taxa, i.e., marine, marinebrackish, brackish, and freshwater based on descriptions reported by Kosugi (1988) and Ando (1990).

Among all cores obtained from the Kobatake-ike pond, the P-14 core was the longest, and there were preliminary radiocarbon data (Yanagisawa et al. 2016). Therefore, we used it for additional high-resolution radiocarbon $\left({ }^{14} \mathrm{C}\right)$ dating to construct an age-depth model. Due to a lack of organic matter, we retrieved seven samples of seeds and plant fragments from the mud layer in the P14 core. Further, in the peat layer, bulk samples were collected at 12 horizons of the P-14 core and 1 horizon of the KBT4 core based on the methods described by Ishizawa et al. (2017). The samples from the KBT4 core were used for correlation of the cores. Then, ${ }^{14} \mathrm{C}$ dating was conducted using accelerator mass spectrometry (AMS, Beta Analytic Inc. in Miami, USA) measurements. The ${ }^{14} \mathrm{C}$ ages were calibrated to the calendar ages using the OxCal 4.3.2 program (Bronk Ramsey 2009a) and the IntCal13 dataset (Reimer et al. 2013). For the P-14 core, we constrained dating results based on stratigraphic order using a sequence model (Bronk Ramsey 2008) and a general outlier model in the OxCal program (Bronk Ramsey 2009b). Then, we constructed an age-depth model. Furthermore, $\delta^{13} \mathrm{C}$ values of organic materials (Table 2) were measured by the elemental analyzer/isotope ratio mass spectrometer (EA/IRMS).

Geochemical signatures are useful as evidence of inland seawater invasion for paleo-tsunami research (Chagué-Goff et al. 2017). High-resolution (1 mm interval) non-destructive $\mathrm{X}$-ray fluorescence (XRF) analysis was conducted using an ITRAX core scanner (e.g., Croudace et al. 2006) (ITRAX; COX Analytical Systems) at the Center for Advanced Marine Core Research at Kochi University to examine the chemical characteristics of event deposits. The Mo tube was used to measure the scattering ratio (Mo inc/Coh), i.e., a proxy for organic matter (Guyard et al. 2007). The voltage and current were set to $30 \mathrm{kV}$ and $55 \mathrm{~mA}$, respectively, and the exposure time was $10 \mathrm{~s}$. The ITRAX elemental data are semiquantitative and affected by core properties such as minerals, grain size, and moisture (Croudace et al. 2006). Therefore, we normalized the measurement values by over total counts (kcps) following the procedures described by Bouchard et al. (2011) and Judd et al. (2017).

\section{Results}

\subsection{Sedimentary facies and stratigraphy}

The lower half of the core was predominantly composed of black peat, which contained several plant fragments (Fig. 2a). Then, a 100-200 cm thick black mud layer 

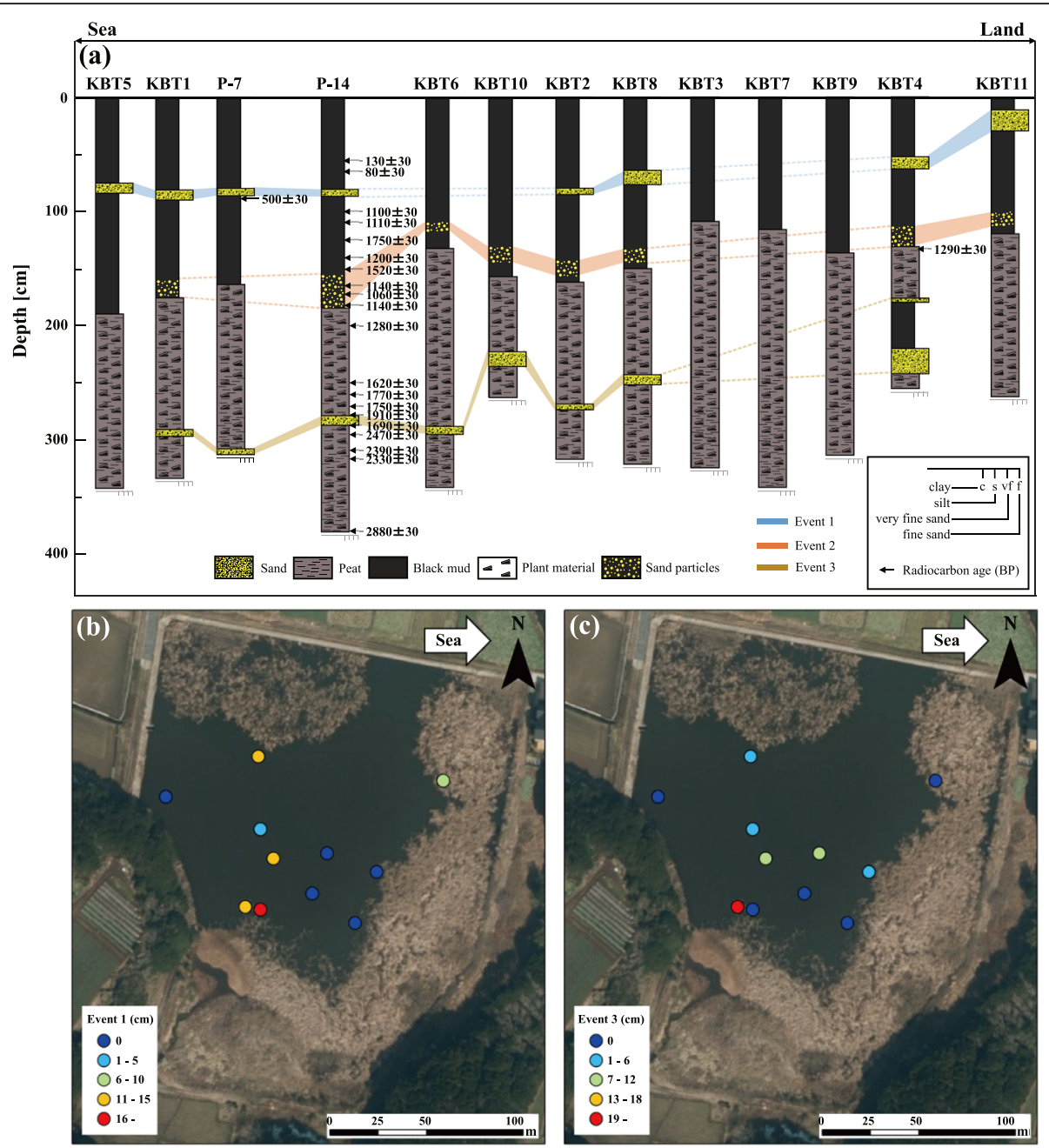

Fig. 2 a Stratigraphic correlation of the geological column of the cores in a sea-land direction. Satellite photographs show the thickness distribution of the $\mathbf{b}$ upper sand layer (event 1) and $\mathbf{c}$ lower sand layer (event 3) in this study

covered the peat layer up to the pond floor. Hereafter, we call the boundary at the mud and peat layers the "mud-peat boundary" because it is expected to indicate significant environmental change at the pond. At the other coring sites, one to three anomalous sand layers consisting of fine to medium sand and locally showing normal grading and inverse grading were interbedded within the peat and mud layers (Table 1). Contacts between the sand and the mud or peat were visually unclear. The CT images showed either clear or blur boundary (Table 1). It was not possible to identify whether or not the contacts were erosive, because the matrix of the sand layer was mud and no rip-up-clast was confirmed in CT images. The thickness of all sand layers was measured carefully by visual observation and CT images (see Additional file 1). The sand layer thickness varied among the cores $(3-22 \mathrm{~cm}$, Table 1 , Fig. $2 \mathrm{~b}$, c). Furthermore, KBT3, KBT7, and KBT9 had no sand layer (see Table 1, Fig. 2b, c). The KBT4 core exhibited slightly different lithology because there seemed to be three sand layers (Fig. 2a). The CT image of the KBT1 core showed a blurred whitish layer with a high CT number above the mud-peat boundary (see Additional file 1). This suggests that a sandy layer may exist above the mud-peat boundary, although they are invisible by visual observation.

Sand particles were detected by microscopic observation of the samples of the whitish layer in KBT1 core (Fig. 3b). The CT images of other cores showed presence of the whitish layer above the mud-peat boundary, similar to the KBT1 core (see Additional file 1). The top and bottom boundaries of the whitish layer are blurred in the CT images. Then, thickness of the whitish layer was determined based on the CT image, using the results of the KBT1 core 
Table 1 Sampling cores and sedimentary characteristics of each sand layer

\begin{tabular}{|c|c|c|c|c|c|c|c|}
\hline Core & $\begin{array}{l}\text { Latitude } \\
\text { (N) }\end{array}$ & $\begin{array}{l}\text { Longitude } \\
\text { (E) }\end{array}$ & $\begin{array}{l}\text { Sand layer depth } \\
(\mathrm{cm})\end{array}$ & $\begin{array}{l}\text { Grain } \\
\text { size }\end{array}$ & $\begin{array}{l}\text { Sedimentary structures } \\
\text { (visual observation) }\end{array}$ & $\begin{array}{l}\text { Basal } \\
\text { contact }\end{array}$ & $\begin{array}{l}\text { Depth of the whitish } \\
\text { layer in the CT images }(\mathrm{cm})\end{array}$ \\
\hline$P-14$ & 35.70985 & 140.85854 & $80-86$ & $m-f^{1)}$ & No & Clear & $155-165$ \\
\hline P-14 & & & $278-287$ & $m-f$ & No & Clear & \\
\hline KBT1 & 35.70992 & 140.85861 & $77-88$ & $m-f$ & No & Clear & $159-171$ \\
\hline KBT1 & & & $289-295$ & $m-f$ & No & Clear & \\
\hline KBT2 & 35.70965 & 140.85862 & $78-83$ & $m-f$ & No & Unclear & $143-156$ \\
\hline KBT2 & & & $266-271$ & $m-f$ & No & Clear & \\
\hline KBT3 & 35.70941 & 140.85886 & - & - & - & - & - \\
\hline KBT4 & 35.70936 & 140.85855 & $53-62$ & $m-f$ & No & Unclear & $113-131$ \\
\hline KBT4 & & & $175-178$ & $m-f$ & No & Clear & \\
\hline KBT4 & & & $219-241$ & $m-f$ & normal grading and inverse & Clear & \\
\hline KBT4 & & & & & & & \\
\hline KBT5 & 35.70983 & 140.85947 & $75-82$ & $m-f$ & No & Clear & - \\
\hline KBT6 & 35.70949 & 140.85916 & $286-292$ & $m-f$ & No & Unclear & $109-116$ \\
\hline KBT7 & 35.70930 & 140.85906 & - & - & - & - & - \\
\hline KBT8 & 35.70954 & 140.85868 & $64-76$ & $m-f$ & No & Clear & $133-145$ \\
\hline KBT8 & & & $243-251$ & $m-f$ & No & Unclear & \\
\hline KBT9 & 35.70977 & 140.85818 & - & - & - & - & - \\
\hline KBT10 & 35.70956 & 140.85893 & $221-233$ & $m-f$ & No & Clear & $131-144$ \\
\hline KBT11 & 35.70935 & 140.85862 & $10-28$ & $m-f$ & No & Clear & $101-113$ \\
\hline
\end{tabular}

as a reference, with some degree of uncertainty (Table 1 and Fig. 2a). Furthermore, Fig. 3 suggests that the samples from the upper and lower sand layers and the middle invisible sand layer (blurred whitish layer in the CT images) have mineralogical compositions similar to the beach sand
(Fig. 3). These sand layers consisted of predominantly quartz, feldspar, and magnetite. The particles of the sand layers are well rounded comparing with that of the beach sand and similar size particles are contained in the beach sand (Fig. 3a, b, c).
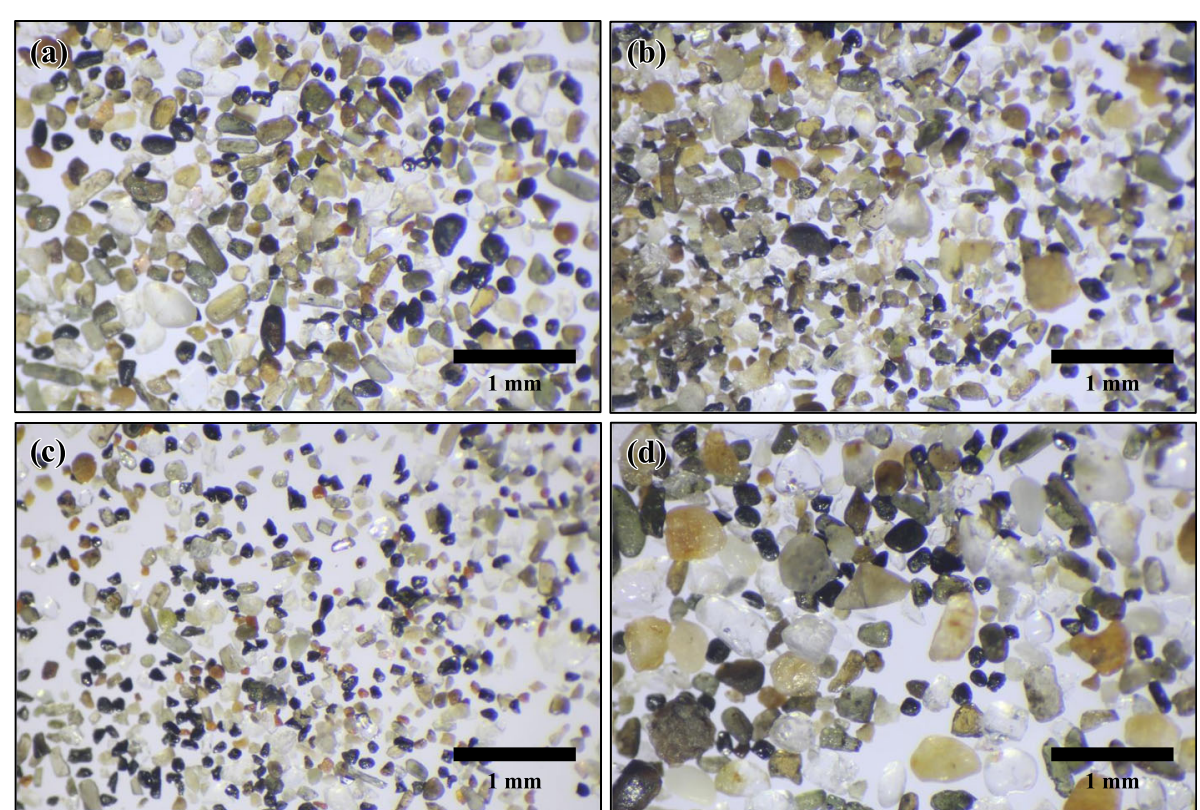

Fig. 3 Microscopic photo of sands contained in the a upper sandy layer (event 1), b above mud-peat boundary (event 2), c lower sandy layer (event 3), and $\mathbf{d}$ the Kimiga-hama beach 


\subsection{Grain size distribution}

The basal sample of sand layer $(241 \mathrm{~cm}$ in depth) in the KBT4 core shows poor sorting and lower $(\sim 30 \%)$ sand content (Fig. 4). However, the remainder of the sand layer is generally well sorted with higher (approximately $80-90 \%)$ sand content and it consists mainly of fine sand (2-3 phi). From 241 to $234 \mathrm{~cm}$ below surface, the sand layer showed upward coarsening in grain size. Then, the grain size distribution of the sand layer changed to the upward fining trend (Fig. 4). Sand contents increases synchronously to the upward coarsening trend. The mud layer above the sand layer $(214-219 \mathrm{~cm}$ below the surface) also includes some sands together with silt or clay size particles (Fig. 4).

\subsection{Diatom analysis}

First, we measured the diatom assemblage at the mudpeat boundary in the P-14 core because it may indicate a critical local environmental change. Generally, freshwater species were predominant at a core depth of 155 $\mathrm{cm}$, whereas few $(<5 \%)$ marine species and approximately $18 \%$ of marine-brackish species were also observed (Fig. 5). The proportion of marine-brackish and brackish species was drastically higher immediately above the mud-peat boundary, while the marine species proportion decreased (Fig. 5). The total percentage of marine and brackish species exceeded 30\% (Fig. 5). At the mud-peat boundary (i.e., $165 \mathrm{~cm}$ ), the percentages of marine, marine-brackish, and brackish species were approximately $0.5 \%, 1 \%$, and $4 \%$, respectively. Below the mud-peat boundary, the percentage of marine, marinebrackish, and brackish species decreased.

At $272-292 \mathrm{~cm}$, the freshwater species were generally dominant, shown by the vertical changes in diatom assemblages (Fig. 5). At a core depth of $272 \mathrm{~cm}$, marine, marine-brackish, and brackish species percentages were approximately $1 \%, 0.5 \%$, and $6 \%$, respectively. In the sand layer located at depths of $278-287 \mathrm{~cm}$ in the P-14, the percentages of marine, marine-brackish, and brackish species were approximately $0.5 \%, 0.5 \%$, and $3 \%$, respectively (284 cm in depth; Fig. 5). The percentages of marine and brackish species were approximately $0.5 \%$ and $2 \%$, respectively, below the sand layer $(292 \mathrm{~cm}$ in depth; Fig. 5).

\subsection{Radiocarbon dating}

The results of radiocarbon dating revealed that the P-14 core presents the geological record from BC 1129 (Table 2, Fig. 6). The age of plant fragments retrieved from the mud layer, i.e., between the upper sand layer and mud-peat boundary at 86 and $165 \mathrm{~cm}$ below the surface, ranged approximately AD 750-1000 (1100-1200 yr BP). Old ages (1520 and $1750 \mathrm{yr}$ BP) were obtained from seeds and organic sediments in the mud layer. In addition, the age (1690 yr BP) of plant material from peat just below the lower sand layer was younger than the ages of peat above

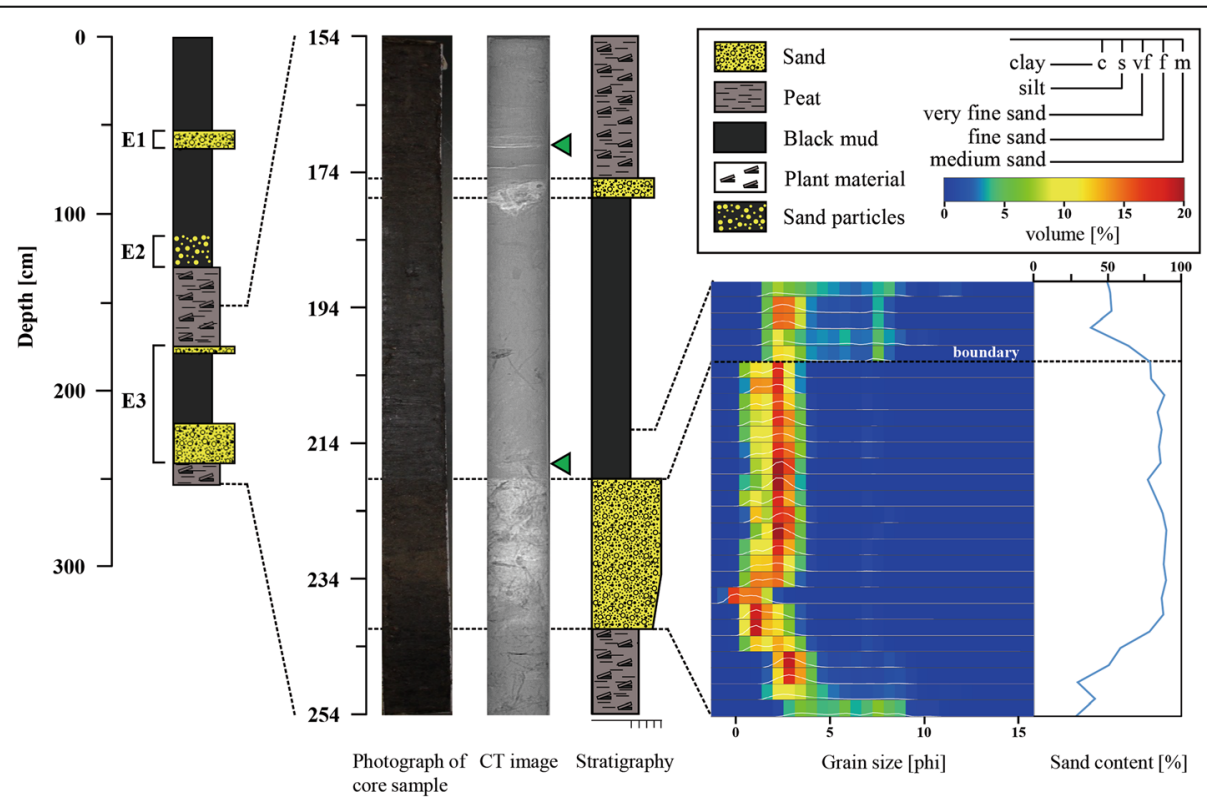

Fig. 4 Columnar section of KBT4 core: a close-up photograph at 154-254 cm depth, CT images, columnar section, grain size, and sand content are also shown. E1, E2, and E3 denote event sand layers. In the CT image, white parts denote sand layers with higher density, whereas gray parts denote mud or peat. White parts represent the apparent direct top of the sand layer (green arrowheads show) in the CT image, indicating that sands were contaminated into the mud layer. For the grain size diagram, the horizontal axis is grain size (phi). The volume percent (\%) of each grain size is indicated by the color scale 


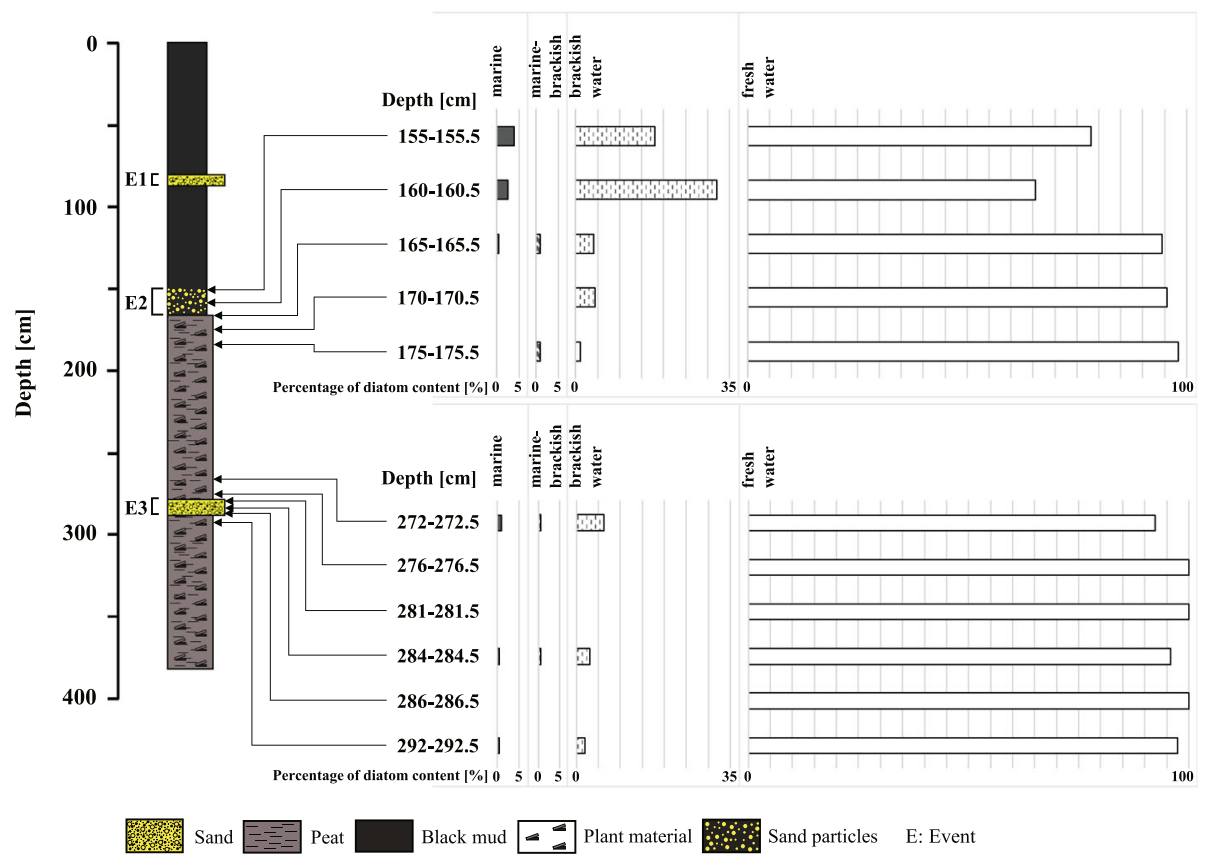

Fig. 5 Relative abundance of diatom assemblages (\%) near the event horizons classified into four salinity groups: freshwater, freshwater-brackish, brackish-marine, and marine

the sand layer (Fig. 6). Because these reversed ages were identified as outliers by a general outlier model in the OxCal program (Bronk Ramsey 2009b), they were not used for estimation of the age ranges of the event deposits. The depositional ages of the sand layer at depths of $80-86 \mathrm{~cm}$, the mud-peat boundary, and the sandy layer at depths of 278-287 cm could be constrained to AD 951-1906, AD

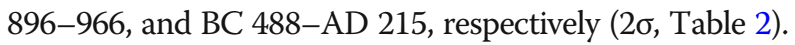

\subsection{Geochemical signatures}

The elemental profiles of the P-14 and KBT4 cores obtained with the ITRAX core scanner are shown in Fig. $7 \mathrm{a}$ and $\mathrm{b}$, respectively. The Mo inc/Coh ratio of the mud layer was generally lower than that of the underlying peat, suggesting that sediments in the mud layer had a low organic matter (Fig. 7a, b).

In the P-14 core, although each elemental profile exhibited subtle variations with the mud and peat layer, the $\mathrm{Si}, \mathrm{K}, \mathrm{Fe}$, and $\mathrm{Ti}$ profiles showed a trend of lower concentration in peaty sediment than in muddy sediment. $\mathrm{Ca}$ and Sr's elemental profiles exhibited a distinct and sharp increase in counts/kcps around the mud-peat boundary at $165 \mathrm{~cm}$ below the surface. Unlike the mud and peat layers, the lower Mo inc/Coh ratios of the sand layers at depths of $80-86 \mathrm{~cm}$ and $278-287 \mathrm{~cm}$ indicate a lack of organic matter. In contrast, the $\mathrm{Si}$ and $\mathrm{K}$ profiles showed a distinct increase in counts/kcps, and slight $\mathrm{Ca}$ and $\mathrm{Sr}$ peaks in counts/kcps occurred in the sand layers. Although $\mathrm{Fe}$ and $\mathrm{Ti}$ concentrations showed no remarkable change in the upper sand layer, a distinct increase was apparent in the lower sand layer. However, the Mn profile had few apparent changes in both sand layers than the mud and peat deposits. The $S$ profile showed no characteristic peak in counts/kcps at the upper and lower sand layers. However, $\mathrm{S}$ and $\mathrm{Ca}$ profiles exhibited a sharp increase in counts/kcps at $275 \mathrm{~cm}$ below the surface, i.e., immediately above the lower sand layer.

Elemental profiles for $\mathrm{Si}, \mathrm{K}, \mathrm{Ti}, \mathrm{Ca}, \mathrm{Sr}$, and $\mathrm{S}$ exhibit subtle variations with the mud and peat layer in the KBT4 core, as similar to the P-14 core (Fig. 7b). Mn and $\mathrm{Fe}$ profiles exhibit greater fluctuations than other elements, but also tend to be slightly low with the mud and peat layer in the KBT4 core (Fig. 7b).

In the KBT4 core, the elements show different profiles between the two sand layers at depths of 175-178 and 219-241 cm. The Mn, Fe, and Ti profiles exhibit a distinct increase in counts/kcps at $175-178 \mathrm{~cm}$ (Fig. 7b). In addition, minor peaks in counts/kcps of $\mathrm{Si}, \mathrm{K}$, and $\mathrm{Ca}$ occur at the same horizon. At depths of $219-241 \mathrm{~cm}, \mathrm{Si}$, $\mathrm{K}, \mathrm{Mn}, \mathrm{Ti}, \mathrm{Ca}, \mathrm{Sr}$, and $\mathrm{S}$ profiles exhibit a distinct increase, whereas the Fe profile also shows a slight increase in counts/kcps (Fig. 7b). By contrast, the profile of the Mo inc/Coh ratio exhibits a distinct decrease at depths of 175-178 cm and 219-241 cm. Furthermore, for $\mathrm{Ca}$ and $\mathrm{S}$, peaks in counts/kcps occur around the mud-peat boundary at $130 \mathrm{~cm}$ below the surface as they do for the P-14 core (Fig. 7b). 
Table 2 Radiocarbon dating results

\begin{tabular}{|c|c|c|c|c|c|c|}
\hline Core & Depth (cm) & Material & Conventional Radiocarbon Age(BP) & Calibrated Age (Cal) & $\delta^{13} \mathrm{C}(\% 0)^{1)}$ & Beta ID \\
\hline $\mathrm{P}-14$ & $45-47$ & plant material & $105.6 \pm 0.4 \mathrm{pMC}$ & NA & -25.5 & 457714 \\
\hline \multirow[t]{2}{*}{ P-14 } & $55-57$ & plant material & $130 \pm 30$ & AD 1670-1780 & -24.4 & 457715 \\
\hline & & & & AD 1800-post 1950 & & \\
\hline \multirow[t]{3}{*}{ P-14 } & $65-67$ & plant material & $80 \pm 30$ & AD 1685-1730 & -24.1 & 457716 \\
\hline & & & & AD 1810-1925 & & \\
\hline & & & & AD 1950- & & \\
\hline$P-14$ & $98-100$ & plant material & $1100 \pm 30$ & AD 885-1015 & -18.3 & 457717 \\
\hline$P-14$ & $108-113$ & plant material & $1110 \pm 30$ & AD 885-995 & -15.9 & 452555 \\
\hline P-14 & 125 & organic sediment & $1750 \pm 30$ & AD 230-380 & -22.6 & 445711 \\
\hline \multirow[t]{2}{*}{ P-14 } & $139-141$ & plant material & $1200 \pm 30$ & AD 720-740 & -17.8 & 457718 \\
\hline & & & & AD 765-895 & & \\
\hline \multirow[t]{3}{*}{ P-14 } & $149-151$ & seeds & $1520 \pm 30$ & AD 430-490 & -19.4 & 457719 \\
\hline & & & & AD 510-515 & & \\
\hline & & & & AD 530-605 & & \\
\hline \multirow[t]{2}{*}{ P-14 } & $165-167$ & organic sediment & $1140 \pm 30$ & AD 775-790 & -27.9 & 452556 \\
\hline & & & & AD 800-980 & & \\
\hline \multirow[t]{2}{*}{ P-14 } & $171-173$ & organic sediment & $1060 \pm 30$ & AD 900-925 & -27.1 & 457720 \\
\hline & & & & AD 945-1020 & & \\
\hline \multirow[t]{2}{*}{$P-14$} & 181-183 & organic sediment & $1140 \pm 30$ & AD 775-790 & -27.8 & 457721 \\
\hline & & & & AD 800-980 & & \\
\hline P-14 & 200 & organic sediment & $1280 \pm 30$ & AD 665-775 & -27.2 & 445712 \\
\hline \multirow[t]{2}{*}{ P-14 } & 250 & organic sediment & $1620 \pm 30$ & AD 385-475 & -23.0 & 445713 \\
\hline & & & & AD 485-535 & & \\
\hline \multirow[t]{2}{*}{$P-14$} & $258-261$ & organic sediment & $1770 \pm 30$ & AD 180-190 & -22.2 & 452557 \\
\hline & & & & AD 215-340 & & \\
\hline P-14 & $271-273$ & organic sediment & $1750 \pm 30$ & AD 230-380 & -22.1 & 457722 \\
\hline \multirow[t]{2}{*}{ P-14 } & $277.5-278.5$ & plant material & $1910 \pm 30$ & AD 30-40 & -27.7 & $J G R^{2)}$ \\
\hline & & & & AD 50-135 & & \\
\hline \multirow[t]{2}{*}{ P-14 } & $287-288$ & plant material & $1690 \pm 30$ & AD 255-295 & -26.5 & $J G R^{2)}$ \\
\hline & & & & AD 320-415 & & \\
\hline P-14 & $292-294$ & organic sediment & $2470 \pm 30$ & BC 770-415 & -23.0 & 452558 \\
\hline P-14 & 310 & organic sediment & $2390 \pm 30$ & BC 540-395 & -26.5 & 445714 \\
\hline$P-14$ & $314-316$ & organic sediment & $2330 \pm 30$ & BC 410-375 & -25.6 & 457723 \\
\hline \multirow[t]{4}{*}{$P-14$} & $378-380$ & organic sediment & $2880 \pm 30$ & BC 1131-973 & -24.7 & 478070 \\
\hline & & & & BC 958-939 & & \\
\hline & & & & BC 1161-1144 & & \\
\hline & & & & BC 1192-1176 & & \\
\hline P-7 & $86.5-88.0$ & plant material & $500 \pm 30$ & AD 1405-1445 & -22.8 & $J G R^{2)}$ \\
\hline KBT4-2 & $132-134$ & organic sediment & $1290 \pm 30$ & AD 664-770 & -27.0 & 487208 \\
\hline
\end{tabular}

\section{Discussion}

5.1 Major environmental change in the Kobatake-ike pond The lithostratigraphy, CT images and radiocarbon $\left({ }^{14} \mathrm{C}\right)$ results showed that general lithology is consistent among the cores in the Kobatake-ike pond during the last 3000 years. The cores showed a lithological change from peat to mud and this is a sole possible major environmental change in this site. The radiocarbon dating indicated that the age of this boundary ranged from AD 896 to $966(2 \sigma)$. Formation of mud and peat layers is generally 


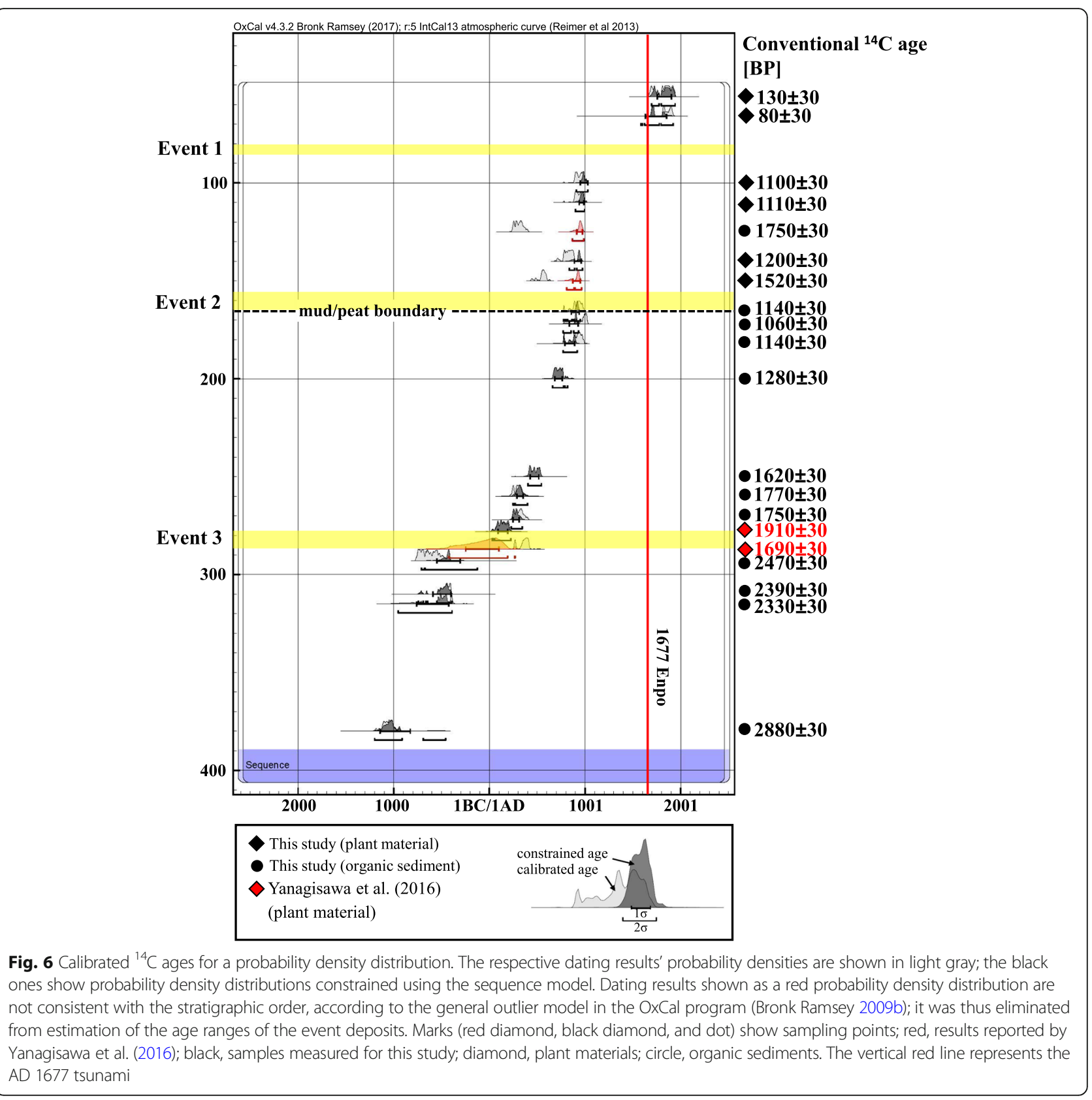

regulated by the balance of plant production and decomposition (Sakaguchi 1974). Peat layer is formed mainly by the deposition of the plant residue that is broken down imperfectly when the plant production is superior to decomposition (Sakaguchi 1974). In the current pond environment, no plants grow in the central part; hence, mud is deposited. Meanwhile, the pond's outer rim is covered by reeds, although there is no marked difference in water depth. Hence, there is a chance that peat is developed in some parts of the present pond. Therefore, it is likely that a slight change in water depth might markedly affect mud or peat layer formation.
The $\delta^{13} \mathrm{C}$ values of the dating materials retrieved from the peat and mud layers provide further evidence for the environmental change in the past Kobatake-ike pond. In the case of aquatic plants in the lake, $\delta^{13} \mathrm{C}$ values of approximately 0 to $-10 \%$ were reported (Watanabe et al. 2010). These values are higher than the range of $\delta^{13} \mathrm{C}$ values (approximately -20 to $-32 \%$, Schwarz and Redman 1988; Watanabe et al. 2010) reported for terrestrial C3 plants.

At the Kobatake-ike pond, dating materials obtained from the peat layer and the top of the mud layer had $\delta^{13} \mathrm{C}$ values corresponding to the isotopic compositions of terrestrial plants, i.e., approximately -22 to $-28 \%$ o (Table 2 ). 

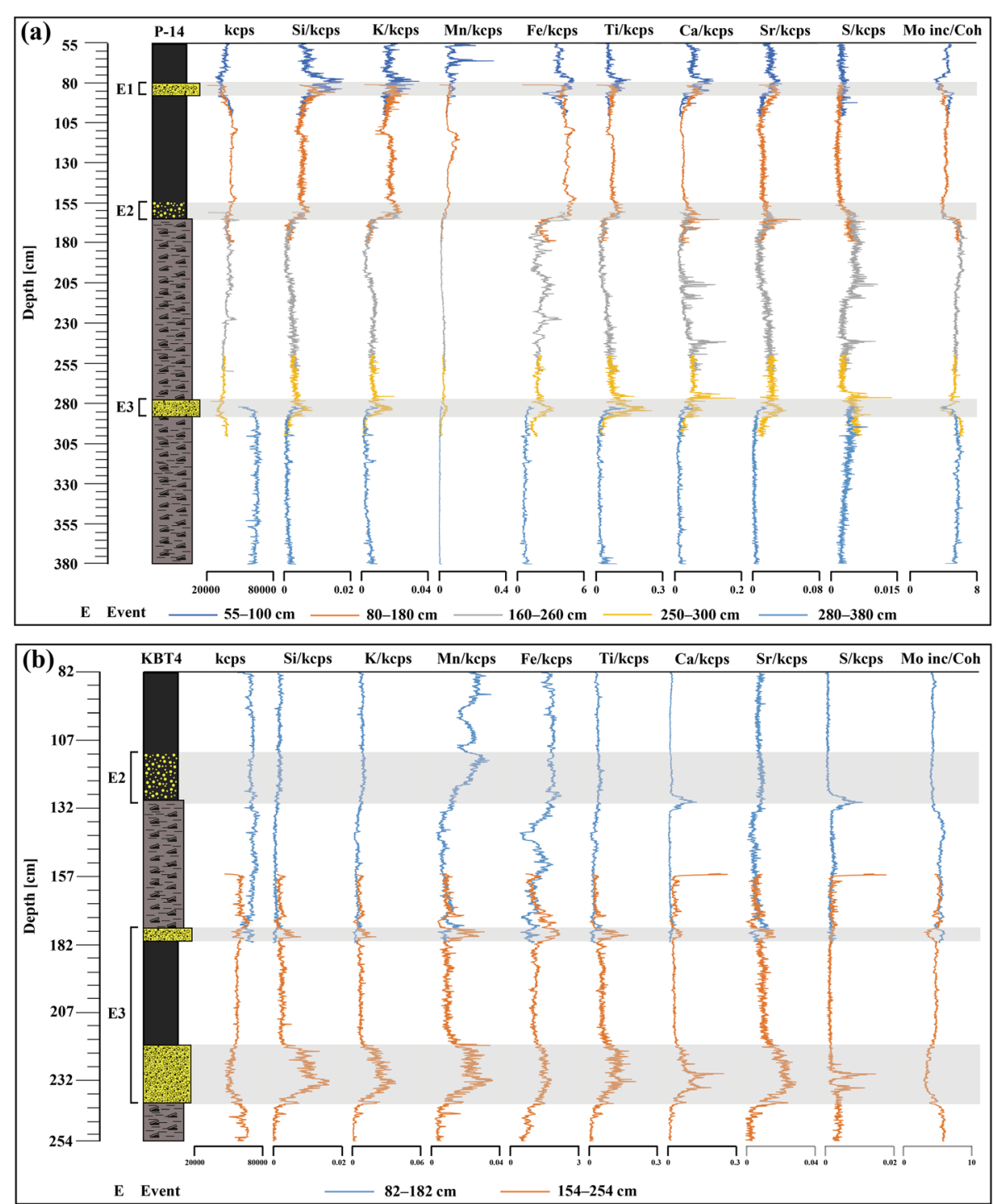

Fig. 7 Normalized ITRAX XRF data of (a) P-14 core (55-380 cm depth) and of (b) KBT4 core (82-254 cm depth). Gray-shaded bars represent depths of the respective sand layers

However, the plants obtained at 76-151 $\mathrm{cm}$ below the surface showed $\delta^{13} \mathrm{C}$ values of approximately -15 to $-19 \%$, with slightly heavier isotope compositions than terrestrial plants (Table 2). These heavy isotope compositions suggest that these plant materials might contain not only terrestrial but also aquatic plant fossils. This implies that the pond's water depth might have increased at the time of mud-peat boundary, which resulted in a change in the depositional environment from a wetland to a pond and led to the vegetation change from terrestrial plants to aquatic plants. To increase the pond's water depth, either an increase in the influx or decrease in the discharge is required. The following two hypotheses can be deduced to explain environmental changes.
1) Hydrological change in the water supply: A factor to increase the water influx to the pond is a spring at Mt. Atago-yama (Yanagisawa et al. 2016), although neither geological nor historical data exist that imply a hydrological change in the spring. Note that no significant river flows into the Kobatake-ike pond.

2) Enclosure of the basin: Considering the historical maps and the present topography, the Kobatake River, i.e., flowing out of the pond, might have been dammed in the past by human activities. This is a reasonable assumption, although there is no historical or geological evidence. In Japan, many small storage reservoirs have been developed earlier than the Edo Period in response to an increase in 
the population and demand for agricultural production (Shirai and Naruse 1983).

In summary, major environmental change from peat to mud in the Kobatake-ike pond can be explained by subtle deepening of water depth either by the natural or artificial processes, although we cannot specify the actual cause(s) and thus further research is required.

\subsection{Identification of event deposits}

Three unusual sandy layers were identified in the Kobatake-ike pond; the upper sand interbedded within the mud, the middle muddy sediment including sand particles above the mud-peat boundary (the middle invisible sand layer) and the lower sand interbedded within the peat, in descending order (Fig. 2). It is noteworthy that the KBT4 core exhibits a different lithology with three sand layers and an isolated black mud between the lower two sand layers (Fig. 2). In other cores, only one sand layer is interbedded within the peat. Interpretation of the lower sand layers in the KBT4 core will be mentioned in the following section. Considering the absence of terrestrial adjacent source of sands, the presence of the sand layers in the pond is unusual. Therefore, we identified them as event deposits. Although the middle invisible sand layer was only identified as a concentration of sand particles with blurred top and bottom boundaries, they were commonly found from many sediment cores (Additional file 1). Therefore, we infer that an unusual deposition of sand might have occurred here.

Based on the lithostratigraphy, CT images and radiocarbon ages, occurrence of the three sandy layers is consistent among the cores. These horizons were named events 1-3 in descending order. The results of the correlation of each event among the cores are shown in Fig. 2.

\subsection{Identification of tsunami deposits}

The Kobatake-ike pond is located on a hill $11 \mathrm{~m}$ above the present sea level, but one must consider its past elevation and sea level when discussing the source of the event deposits. In the Choshi Peninsula, even when considering tectonic uplift and sea-level changes, this pond is regarded as having been located on a hill far from the sea for the last 3000 years (Kashima et al. 1990; Ota et al. 1985). Yanagisawa et al. (2016) reported that no historical or instrumental records suggest pond inundation by storm surges or waves over the last 400 years. They also excluded the possibility of storm wave deposition in the pond. Through numerical simulations of the 1677 Enpo tsunami in the Kobatake-ike pond, they revealed that an earthquake with a magnitude $(\mathrm{Mw})$ greater than 8.3 is necessary for tsunami waves to inundate the Kobatake-ike pond. Therefore, we inferred that only large-scale tsunamis could inundate the Kobatake- ike pond. The pond is surrounded by the Late Pleistocene marine terraces, and terrestrial weathering might have produced some amount of sandy sediments, which can be a source of the event deposits. Nevertheless, there is no cliff around the Kobatake-ike pond supplying the sandy deposits into the pond. Furthermore, it is unlikely that relatively frequent processes, such as typhoons or floods, have supplied such weathered sediments to the Kobatake-ike pond, because the deposition of the sand is quite infrequent; it is only three times during the period from BC 1129 to AD 1950. Therefore, even if the source of part of sands was the Late Pleistocene terraces, they might not have been eroded unless the infrequent and large event such as tsunamis.

The mineralogical composition of the sands is another important evidence to identify the source of the event deposits. All event deposits consisted of predominantly quartz, feldspar, and magnetite (Fig. 3) and these minerals are commonly found in the beach sand (Sudo 2006). Indeed, our microscopic observation showed that quartz, feldspar, and magnetite are main contents of the present beach sand of Kimiga-hama (Fig. 3). This suggests that the source of the event sands is the beach, and it can be considered that a strong flow of seawater eroded the beach sands and transported them into the Kobatake-ike pond.

The grain-size analysis revealed that event 3 (e.g., KBT4 core) shows normal grading and inverse grading (see Fig. 4). A similar sedimentary structure is typically reported for deposits formed by recent massive tsunamis such as the 2011 Tohoku-oki tsunami (Nakamura et al. 2012; Naruse et al. 2012) and the 2004 Indian Ocean tsunami (Naruse et al. 2010). Naruse et al. (2010) propose that inverse grading occurs during the waxing stage of oscillatory flows, such as tsunami run-up or backwash flows; then, the graded part is formed during the waning stage. Moreover, Sawai (2012) reported that inverse grading can be interpreted as grain coarsening because of suspended sediment passage with flow acceleration. Furthermore, Moreira et al. (2017) report inverse or massive sedimentary sequences in the basal section of AD 1755 Lisbon tsunami deposits. They attributed these sequences to the dominance of bedloaddominated transport and deposition regarded high flow velocities and high-density sediment loads during the tsunami inundation (e.g., Jaffe et al. 2012).

Diatom and geochemical signatures are generally used as one of proxies of seawater inundation for paleotsunami research (e.g., Chagué-Goff 2010; Hadler et al. 2015; Judd et al. 2017; Minoura and Nakaya 1991; Ramírez-Herrera et al. 2012; Williams et al. 2011). For example, higher $\mathrm{Ca}$ and $\mathrm{Sr}$ concentrations are useful as seawater indicators because $\mathrm{Ca}$ and $\mathrm{Sr}$ concentrations in seawater are generally higher than those in freshwater 
(Wedepohl 1971). Moreover, higher sulfur (S) concentrations can be considered as a proxy of paleosalinity, due to the higher availability of sulfate in seawater than in freshwater (Casagrande et al. 1977; Chagué-Goff 2010; Goff et al. 2012).

In this study, however, not all proxies of diatom and geochemical signatures have been identified in each event layer (Table 3). In the P-14 core, diatom analysis showed that marine and brackish species are observed at event 2 and also a few marine, marine-brackish, and brackish species are all found in event 3 . It is noteworthy that marine and brackish species were also observed in the normal sediments below events 2 and 3 (Fig. 5), although diatoms of marine and brackish species are not originally produced in the normal sediments in the pond (Yanagisawa et al. 2016). Geochemical signatures indicating seawater, such as salinity, do not remain in the porous sand layers and flow down to the bottom soil by rainwater (e.g., Chagué-Goff et al. 2015). These indicators tend to be preserved in organic or fine sediments (e.g., Chagué-Goff 2010). Likewise, diatoms may migrate downward in porous sediments. Chiba et al. (2015) demonstrated possible migration of diatoms from a porous sandy deposit to underlying layer, based on constant head permeability test. Yanagisawa et al. (2016) observed marine-brackish species in the muddy sediment immediately below the AD1677 Enpo tsunami deposit, and argued that the downward migration of diatoms might have occurred. Considering such observations, diatoms originally included in event 3 might have migrated downward through the porous peat layer. Furthermore, the presence of marine-brackish diatoms in the muddy sediment above event 3 indicates that the horizon must be included in event 3 , since the grain size data and CT images suggested that the horizon indicated significant sandy fractions (see Fig. 4).

Elemental profiles of the P-14 core showed higher Ca and $\mathrm{Sr}$ concentrations in events 1 and 2, although no peak of S concentrations was observed (Fig. 7a). However, in the profile of the KBT4 core, the higher $\mathrm{Ca}$ and S clear peaks in counts/kcps were recognized in the bottom of event layer 2, but $\mathrm{Sr}$ concentrations were not significantly different from the normal sediments (Fig. 7b). For event 3, all seawater indicators $(\mathrm{Ca}, \mathrm{Sr}$, and $\mathrm{S}$ ) were found in both the P-14 and KBT4 cores. However, note that the higher $\mathrm{Ca}$ and $\mathrm{S}$ clear peaks in counts/kcps are recognized immediately above event 3 than in sand layer (Fig. 7a). These results show that the mud immediately above event 3 is probably a mud cap (e.g., Ishizawa et al. 2019). Although the diatom and geochemical signatures from events 1-3 partially indicated that the Kobatake-ike pond was inundated by seawater, these indicators are not necessarily consistent among the event layers. Various factors, such as local variability of initial thickness and preservation condition of the event layer and the downward migration of diatom and elements, may be involved in the limited applicability of the proxies in this case.

Considering the geomorphological, sedimentological, and mineralogical evidences together with supportive paleontological and geochemical evidences, we identified the deposits of events 1-3 as tsunami deposits and the sediment source of them as the beach sand at Kimiga-hama.

\subsection{Interpretation of a different lithology (i.e., 175-219 $\mathrm{cm}$ ) in the KBT4 core}

The KBT4 core shows slightly different lithology. However, the thin sand layer (i.e., $175-178 \mathrm{~cm}$ ) and an isolated black mud (i.e., $178-219 \mathrm{~cm}$ ) were not observed in the other cores. ITRAX analysis of the KBT4 core reveals that profiles of $\mathrm{Ca}$ and $\mathrm{Sr}$ (indicators of seawater), and $\mathrm{Si}$ and $\mathrm{K}$ (rock-forming minerals) exhibit a distinct increase in this sand layer. Profiles of other elements also show a similar trend to that of the lower sand layer (i.e., 219-241 cm, Fig. 7).

Three hypotheses for this sand layer can be considered.

(1) The sand layer is an independent event from events $1-3$. This possibility is nevertheless unlikely because no event layer that can be compared with this sand layer was identified in other cores.

(2) The sand layer was formed by the tsunami that deposited the lower sand layer (i.e., $219-241 \mathrm{~cm}$ ). Tsunami waves bearing coastal sands invaded into the pond and stirred up muddy sediments to form a thick sand layer (event 3). Subsequently, the deposited sand was raised again by the wave, which was reflected in the pond edge and which was deposited again with original pond

Table 3 Proxy check list of event sand layers in the cores (P-14 and KBT4)

\begin{tabular}{lllllll}
\hline Core & Event & \multicolumn{2}{l}{ Diatom } & & \multicolumn{2}{l}{ Geochemical signatures } \\
\cline { 3 - 6 } & & marine & marine-brackish & brackish & Ca & Sr \\
\hline P-14 & E1 & - & - & - & $\checkmark$ & $\checkmark$ \\
& E2 & $\checkmark$ & $\checkmark$ & $\checkmark$ & $\checkmark$ & $\checkmark$ \\
\multirow{2}{*}{ KBT4 } & E3 & $\checkmark$ & $\checkmark$ & - & $\checkmark$ & $\checkmark$ \\
& E2 & - & - & - & $\checkmark$ & $\checkmark$ \\
\hline
\end{tabular}


sediment. However, the environmental change in the Kobatake-ike pond demonstrated by the mud-peat boundary suggests that the pond was a wetland at time of event 3. Therefore, it is unlikely that tsunami waves stirred up and redeposited approximately $20 \mathrm{~cm}$ thick mud due to shallow water depth.

(3) KBT4 might have been located at a local topographic low in the wetland, such as a little channel. The thickness of sand layer (event 3) at the KBT4 and the adjacent core P-21 (Yanagisawa et al. 2016) is much thicker than that at other cores, suggesting that thick sediments may have been formed in the topographic low. The black mud is a reworked sediment after event 3. The thin sand layer in the KBT4 core (i.e., 175-178 $\mathrm{cm})$, with indicators of seawater, can be considered as a reworked sediment which was derived from the sandy tsunami deposit (i.e., event 3 ) in the surrounding areas. Considering the locality of the sites and thickness of the sand layer, this seems much more plausible among the three hypotheses.

Therefore, we do not treat this thin sand layer in the KBT4 core as an independent event. We inferred that this sand layer was formed locally in association to the event 3 .

\subsection{Depositional age of event deposits from age-depth model}

Depositional ages of event 1 (i.e., $80-86 \mathrm{~cm}$ ), event 2 (i.e., 155-165 cm; a whitish layer containing minor sand particles in CT images), and event 3 (i.e., $278-287 \mathrm{~cm}$ ) were estimated to be AD 951-1906, AD 899-971, and BC 488-AD 215, respectively based on the age-depth model (Fig. 6). Yanagisawa et al. (2016) identified the sand layer in the Kobatake-ike pond as the 1677 Enpo tsunami deposit based on the multiple analyses of tephra, microfossil and historical documents, and radio-

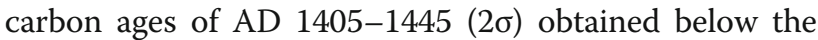
layer (Yanagisawa et al. 2016). Our results are consistent with their interpretation.

The age of event 2 includes a large uncertainty. It might be readily apparent from the age-depth model (Fig. 6) that the sedimentation rate changes suddenly at the mud-peat boundary. The rate below the boundary is approximately $1 \mathrm{~m} / \mathrm{kyr}$ which is a common sedimentation rate in a wetland (Sakaguchi 1974), while above the boundary is $2.7 \mathrm{~m} / \mathrm{kyr}$. If this sedimentation rate is reflective of actual conditions, the deposition of the mud (approximately $80 \mathrm{~cm}$ ) between events 1 and the mudpeat boundary occurred within approximately 100 years (Fig. 6). Furthermore, a large time gap separates the layers below and above that mark the 1677 tsunami deposit (event 1). As reported for the 2011 Tohoku-oki tsunami, a tsunami can erode the original sediment in the coastal pond. Such significant erosion can result in a large time gap below the tsunami deposit (Shinozaki et al. 2015). However, approximately $4 \mathrm{~m}$ thick sediment is expected to have been eroded by the tsunami associated with event 1 (=1677 Enpo tsunami) if we consider the sedimentation rate between events 1 and the mudpeat boundary. Such significant erosion is unlikely to have occurred at the high elevation of the Kobatake-ike pond, together with a historical account of the 1677 Enpo tsunami. In addition, the water depth of the pond is small, and it cannot accommodate such a thick sediment. Yanagisawa et al. (2016) reported that radiocarbon dating of plant materials obtained from the muddy sediment below event 1 (core P-7; Yanagisawa et al. 2016) ranged from $\mathrm{AD} 1405$ to 1445 . Therefore, erosion of the pond floor sediment by the 1677 tsunami should have been limited. Alternatively, the following two hypotheses can be regarded as explaining this change in sedimentation rate and time gap beneath event 1 .

\subsubsection{Tsunami-induced sediment mixing related to event 2}

The possibility exists that the age-depth model was affected by a mechanical depositional process to mix the soft muddy sediment. Two possible depositional processes can be considered such as tsunami inundation and human activity. However, there is no historical evidence suggesting that the pond sediments have been disturbed by human activity. Therefore, this section explains the possible depositional process due to the tsunami inundation. Shinozaki et al. (2015) reported for Suijin-numa pond in Sendai Plain that the original muddy sediment was eroded and suspended by the Tohoku-oki tsunami to form an approximately $50 \mathrm{~cm}$ thick reworked mud layer above sandy tsunami deposits. According to radiocarbon dating of the reworked mud layer, the ages obtained from the mud layer were almost homogenized. They reported that the muddy tsunami deposits contained a mixture of organic materials of various ages during the last 1100 years due to tsunami erosion. Such homogenized ages in the mud layer of a pond are similar to our dating results obtained between events 1 and the mud-peat boundary (Fig. 6). In addition, our study revealed that the Kobatake-ike pond was inundated by the tsunami at event 2 immediately above the mud-peat boundary. Thus, erosion and deposition of reworked mud might have occurred due to the tsunami at event 2 . If tsunami-induced reworking of the mud has taken place, the mud layer above the boundary represents an age older than the actual tsunami age. If this model is correct, it is difficult to restrict the limiting minimum age of event 2 using homogenized radiocarbon dating results, although the limiting maximum age of AD 896-954 is unaffected because the age was obtained from the hard peat layer below the mud-peat boundary, which can be regarded as having not been 
reworked. The homogenized mud should have been terminated below event 1 (1677 Enpo tsunami deposit) because radiocarbon age of plant materials obtained from the mud below event 1 was AD 1405-1445 (Yanagisawa et al. 2016), which is much younger than the homogenized age. The radiocarbon dating result can also be used as a reliable limiting minimum age of event 2 and also as a limiting maximum age of event 1 .

\subsubsection{Reservoir effect}

The dissolved inorganic carbon in water used for photosynthesis by aquatic plants has a lower ${ }^{14} \mathrm{C}$ concentration than in the atmosphere because of seawater and freshwater reservoir effects. Therefore, the radiocarbon dating values of aquatic plant fossils are known to tend to be older than the actual age (Kilian et al. 1995; Watanabe et al. 2010). For example, Kilian et al. (1995) performed radiocarbon dating using aquatic plants in raised bog deposits. They reported that these results were strongly affected by local reservoir effects and reported dates hundreds of years older than the actual age. At the Kobatake-ike pond, the $\delta^{13} \mathrm{C}$ values of dating materials obtained from the mud layer between events 1 and the mud-peat boundary show slightly heavier isotope compositions than those of terrestrial plants (Table 2). These heavy isotope compositions suggest that these plant materials might contain aquatic plant fossils not only terrestrial plants. If this is the case, the radiocarbon ages obtained from the mud layer between events 1 and the mud-peat boundary might be affected by local reservoir effects and might represent hundreds of years older than the actual age.

In either case, the age of event 2 cannot be sufficiently constrained. Considering the uncertainty in radiocarbon dating, the tsunami of event 2 might have occurred during the 10th to fifteenth centuries (AD 896-1445), although no written record is known for such a tsunami event. The relocation of the shrine at AD 976 (Choshi Geopark Promotion Council 2016) can be related to the tsunami; however, the age of the relocation is based only on the local traditional knowledge, for which the reliability has not yet been evaluated. Further investigation is needed to constrain the age of the tsunami event between the tenth and fifteenth centuries.

As for event 3, similar to the Suijin-numa case (Shinozaki et al. 2015), the tsunami-induced sediment mixing might only occur in the softer mud layer: it might not occur in the peat layer because they possess a higher erosion threshold than mud (Jacobs et al. 2011; Otsubo and Muraoka 1988; Tuukkanen et al. 2014). Homogenized dating results cannot be ascertained above and below event 3 (Fig. 6), which is intercalated within the harder peat layer. Therefore, it is unlikely that the tsunami-induced reworking affected the radiocarbon ages of event 3 (BC 488-AD 215).

\subsection{Paleotsunami history along the southern and central part of Japan Trench}

Our results demonstrated that three massive tsunamis struck the studied area during the past 3000 years: $A D$ 1677, AD 896-1445, and BC 488-AD 215. Although age restrictions of tsunami events in the southern part of the Japan Trench are poor, it is noteworthy that the timing of the paleo-tsunami events is overlap to the ages of known paleotsunamis in the central part of the Japan Trench, and hence there may be a possible spatiotemporal relation of earthquake generations between the central and southern parts of the Japan Trench (Fig. 8).

Sawai et al. (2012) conducted a comprehensive survey along the Pacific coast from Miyagi Prefecture to northern Ibaraki Prefecture. They identified five large tsunami events based on historical and geological evidence and inferred that they were formed by the AD 1611 Keicho, AD 1454 Kyotoku, and AD 869 Jogan tsunamis and older tsunamis at AD 400-500 and BC 500-400. Saino (2012) and Matsumoto et al. (2013) reported that a tsunami struck the Sendai Plain around 2050 yr BP, which was not reported by Sawai et al. (2012) (see also discussion by Sawai 2020).

The AD 1677 Enpo tsunami occurred in the southern part of the Japan Trench approximately 60 years after the AD 1611 Keicho tsunami (Fig. 8). The evidence for seawater inundation in event 2 suggests that a large tsunamigenic earthquake struck the Choshi region during tenth-fifteenth centuries (AD 896-1445) and the possible known tsunami around AD 976 at Choshi City, which seems close to the AD 869 Jogan tsunami, is one candidate. In addition, since the age cannot be constrained well, the age range of event 2 is also close to the AD 1454 Kyotoku tsunami (Sawai et al. 2015). The radiocarbon ages showed that event 3 was deposited between BC 488 and AD 215. The age overlaps either to the event in 2050 yr BP (Matsumoto et al. 2013; Saino 2012) and in BC 500-400 (Sawai et al. 2012) along the central part of the Japan Trench. However, age ranges of events 2 and 3 cannot be sufficiently constrained. Therefore, further age constraint for the events 2 and 3 is required.

No visible event deposit that can overlap to the $\mathrm{AD}$ 400-500 tsunami event reported in the central part of the Japan Trench (Sawai et al. 2012) was identified in the cores obtained from the Kobatake-ike pond (Fig. 8). The ITRAX result showed no geochemical evidence indicating seawater invasion and even suggests that the event without a sandy deposit is less likely to exist (Fig. 7). Therefore, no massive tsunami was generated during this period in the southern part of the Japan Trench. Alternative explanations are that the tsunami could not reach the elevation of the 


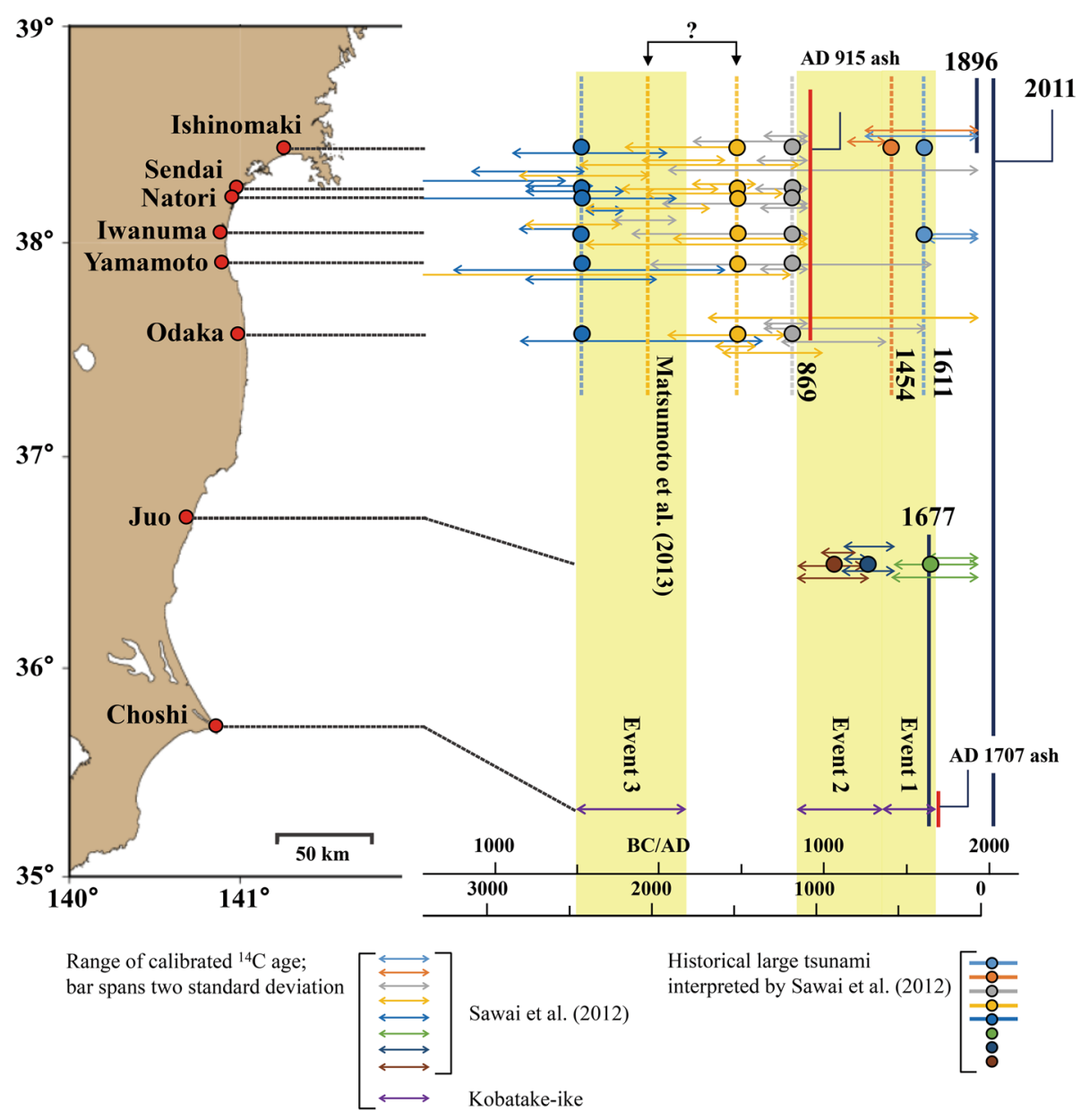

Range of event age confirmed in Kobatake-ike Pond

Fig. 8 Paleotsunami histories in the Pacific coasts from Miyagi to Chiba Prefecture, which faces the central and southern parts of Japan Trench

Kobatake-ike pond $(11 \mathrm{~m})$ or the tsunami reached but the deposits were eroded by later tsunamis. However, the CT images and ITRAX profiles did not provide useful information to assess whether or not the event deposits had been eroded.

The discussion presented above related to the correlation of paleo-tsunami histories between the central and southern parts of the Japan Trench might indicate important spatiotemporal relations of large earthquakes in these areas. However, since the error ranges of the ages of both tsunami deposits are large, further investigation is required to clarify the relations of large earthquakes in both areas.

\section{Conclusions}

We identified three tsunami events occurring during the past 3000 years from sediment cores obtained at the Kobatake-ike pond. The uppermost tsunami deposit can be correlated with the AD 1677 Enpo tsunami. Radiocarbon dating results further indicated that the older tsunamis might have occurred at AD 896-1445 and BC 488-AD 215. Additionally, the results show that the paleo-tsunami histories in the central and southern parts of the Japan Trench may occur in a relatively short-time interval, although the error ranges of both tsunami deposits at the southern and central parts of the Japan Trench are large. This result implies the possibility that a spatiotemporal relation of large earthquake generations (strain accumulation and release) might exist between the central and southern parts of the Japan Trench areas. This possibility should be considered in tsunami hazard assessments.

Abbreviations

yr BP: Years before present 


\section{Supplementary Information}

The online version contains supplementary material available at https://doi. org/10.1186/s40645-021-00415-w.

Additional file 1: Figure S1. $C T$ image of Core $K B T 1$ visualized by 3D Slicer, a free and open-source platform for analyzing and understanding medical image data. Figure S2. CT image of Core KBT2 visualized by 3D Slicer, a free and open-source platform for analyzing and understanding medical image data. Figure S3. CT image of Core KBT4 visualized by 3D Slicer, a free and open-source platform for analyzing and understanding medical image data. Domain outlined by the white rectangle shows that the sampling area for grain size analyses (214-241 cm depth). Figure S4. CT image of Core KBT6 visualized by 3D Slicer, a free and open-source platform for analyzing and understanding medical image data. Figure S5. CT image of Core KBT8 visualized by 3D Slicer, a free and opensource platform for analyzing and understanding medical image data. Figure S6. CT image of Core KBT10 visualized by 3D Slicer, a free and open-source platform for analyzing and understanding medical image data. Figure S7. CT image of Core KBT11 visualized by 3D Slicer, a free and open-source platform for analyzing and understanding medical image data. Figure S8. CT image of Core P-14 visualized by 3D Slicer, a free and open-source platform for analyzing and understanding medical image data. Figure S9. Grain size distribution of Core KBT4 $(214-217 \mathrm{~cm}$ depth). Figure S10. Grain size distribution of Core KBT4 $(217-229 \mathrm{~cm}$ depth). Figure S11. Grain size distribution of Core KBT4 $(229-241 \mathrm{~cm}$ depth). Table S1. Result of diatom assemblage analysis

\section{Acknowledgements}

We appreciate the landowner for giving us permission to perform the surveys. CT imaging and non-destructive XRF analyses were conducted at the Center for Advanced Marine Core Research at Kochi University (accept no. 16A008, 16B008, 17A005, and 17B005). Dr. K. Ikehara, Dr. P. J. M. Costa, and an anonymous reviewer provided valuable comments that improved the manuscript. We thank all of these people for their support.

\section{Authors' contributions}

$H H, K G, H Y$, and DS conducted fieldwork and collected samples. KG proposed the study topic and conceived and designed the study. $\mathrm{HH}$ and TI picked out organic materials for radiocarbon dating and constrained event ages by OxCal. $\mathrm{HH}$ led the writing of the text and preparation of the figures. All authors participated in discussions during the research, later reading, and approval of the final manuscript.

\section{Funding}

This research was supported by research funding from JSPS KAKENHI Grant Number JP17H02971 and by FY2020 grant-in-aid for joint research from IRIDeS, Tohoku University, and was supported as a commissioned project of the Nuclear Regulation Authority.

\section{Availability of data and materials}

Please contact author for data requests.

\section{Declarations}

\section{Competing interests}

The authors declare that they have no competing interests.

\section{Author details}

'Department of Earth Sciences, Graduate School of Science, Tohoku University, Sendai 980-8578, Japan. ${ }^{2}$ International Research Institute of Disaster Science, Tohoku University, 468-1 Aza-Aoba, Aramaki, Aoba-ku, Sendai 980-0845, Japan. ${ }^{3}$ Department of Earth and Planetary Science, The University of Tokyo, 7-3-1 Hongo, Bunkyo-ku, Tokyo 113-0033, Japan. ${ }^{4}$ Department of Regional Management, Tohoku Gakuin University, 1-3-1 Tsuchitoi, Aoba-ku, Sendai 980-8511, Japan. ${ }^{5}$ Museum of Natural and Environmental History, Shizuoka 5762 Oya, Suruga-ku, Shizuoka, Shizuoka Prefecture 422-8017, Japan.
Received: 30 July 2020 Accepted: 3 March 2021

Published online: 25 April 2021

\section{References}

Ando K (1990) Environmental indicators based on freshwater diatom assemblages and its application to reconstruction of paleo-environments. Annals of The Tohoku Geographycal Asocciation 42:73-88. doi:https://doi. org/10.5190/tga1948.42.73 (in Japanese, with English abstract)

Boespflug X, Long BFN, Occhietti S (1995) Cat-scan in marine stratigraphy: a quantitative approach. Mar Geol 122:281-301. https://doi.org/10.1016/002 5-3227(94)00129-9

Bondevik S, Svendsen J, Johnsen G, Mangerud J, Kaland PE (1997) The Storegga tsunami along the Norwegian coast, its age and run up. Boreas 26:29-53. https://doi.org/10.1111/j.1502-3885.1997.tb00649.x

Bouchard F, Francus P, Pienitz R, Laurion I (2011) Sedimentology and geochemistry of thermokarst ponds in discontinuous permafrost, subarctic Quebec. Canada. J Geophys Res 116. https://doi.org/10.1029/2011JG001675

Bronk Ramsey C (2008) Deposition models for chronological records. Quat Sci Rev 27:42-60. https://doi.org/10.1016/j.quascirev.2007.01.019

Bronk Ramsey C (2009a) Bayesian analysis of radiocarbon dates. Radiocarbon 51: 337-360. https://doi.org/10.1017/S0033822200033865

Bronk Ramsey C (2009b) Dealing with the outliers and offsets in radiocarbon dating. Radiocarbon 51:1023-1045. https://doi.org/10.1017/S0033822200034093

Casagrande DJ, Siefert K, Berschinski C, Sutton N (1977) Sulfur in peat-forming systems of the Okefenokee Swamp and Florida Everglades: origins of sulfur in coal. Geochim Cosmochim Acta 41:161-167. https://doi.org/10.1016/00167037(77)90196-X

Chagué-Goff C (2010) Chemical signatures of palaeotsunamis: a forgotten proxy? Mar Geol 271:67-71. https://doi.org/10.1016/j.margeo.2010.01.010

Chagué-Goff C, Goff J, Wong HKY, Cisternas M (2015) Insights from geochemistry and diatoms to characterise a tsunami's deposit and maximum inundation limit. Mar Geol 359:22-34. https://doi.org/10.1016/j.margeo.2014.11.009

Chagué-Goff C, Szczuciński W, Shinozaki T (2017) Applications of geochemistry in tsunami research: a review. Earth Sci Rev 165:203-244. https://doi.org/10.101 6/j.earscirev.2016.12.003

Chiba T, Takemura T, Uemura K (2015) Effect of the diatom fossils infiltration on the lower layer diatom fossil assemblages. Abstract O3 presented at the JSD 36th Meeting, The University of Tokyo, Japan, 9-10 May 2015. Diatom 31:5664 (in Japanese) http://diatomology.org/eng/diatom/list/diatom_abstracts/dia tom31_56-64.pdf

Choshi Geopark Promotion Council (2016) A story of blessings of nature and the disaster. http://www.choshi-geopark.jp/file/saigai.pdf. (in Japanese).

Croudace IW, Rindby A, Rothwell RG (2006) ITRAX: description and evaluation of a multi-function new X-ray core scanner. Geol Soc Lond Spec Publ 267:5163. https://doi.org/10.1144/GSL.SP.2006.267.01.04

Cuven S, Paris R, Falvard S, Miot-Noirault E, Benbakkar M, Schneider J-L, Billy I (2013) High-resolution analysis of a tsunami deposit: case-study from the 1755 Lisbon tsunami in southwestern Spain. Marine Geology 337:98-111. https://doi.org/10.1016/j.margeo.2013.02.002

Falvard S, Paris R (2017) X-ray tomography of tsunami deposits: towards a new depositional model of tsunami deposits. Sedimentology 64:453-477. https:// doi.org/10.1111/sed.12310

Falvard S, Paris R, Belousova M, Belousov A, Giachetti T, Cuven S (2018) Scenario of the 1996 volcanic tsunamis in Karymskoye Lake, Kamchatka, inferred from X-ray tomography of heavy minerals in tsunami deposits. Mar Geol 396:160170. https://doi.org/10.1016/j.margeo.2017.04.011

Goff J, Chagué-Goff C, Nichol S, Jaffe B, Dominey-Howes D (2012) Progress in palaeotsunami research. Sedi Geol 243-244:70-88. https://doi.org/10.1016/j. sedgeo.2011.11.002

Goto K, Ishizawa T, Ebina Y, Imamura F, Sato S, Udo K (2021) Ten years after the 2011 Tohoku-oki earthquake and tsunami: geological and environmental effects and implications for disaster policy changes. Earth Sci Rev 212:103417. https://doi.org/10.1016/j.earscirev.2020.103417

Goto T, Satake K, Sugai T, Ishibe T, Harada T, Gusman AR (2019) Tsunami history over the past 2000 years on the Sanriku coast, Japan, determined using gravel deposits to estimate tsunami inundation behavior. Sedi Geol 382:85102. https://doi.org/10.1016/j.sedgeo.2019.01.001

Goto T, Satake K, Sugai T, Ishibe T, Harada T, Murotani S (2015) Historical tsunami and storm deposits during the last five centuries on the Sanriku coast, Japan. Mar Geol 367:105-117. https://doi.org/10.1016/j.margeo.2015.05.009 
Guyard H, Chapron E, St-Onge G, Anselmetti FS, Arnaud F, Magand O, Francus P, Mélières M-A (2007) High-altitude varve records of abrupt environmental changes and mining activity over the last 4000 years in the Western French Alps (Lake Bramant, Grandes Rousses Massif). Quat Sci Rev 26:2644-2660. https://doi.org/10.1016/j.quascirev.2007.07.007

Hadler H, Baika K, Pakkanen J, Fischer P, Henning P, Ntageretzis P, Robke B, Willershauser T, Vött A (2015) Palaeotsunami impact on the ancient harbour site Kyllini (western Peloponnese, Greece) based on a multiproxy approach. Z Geomorphol Suppl 59:7-41. https://doi.org/10.1127/ zfg_suppl/2014/S-00187

Hatori T (2003) Irregular height deviation of the 1677 Enpo Boso-Oki tsunami, eastern Japan. Hist Earthq 19:1-7 (in Japanese, with English abstract)

Inoue T, Goto K, Nishimura Y, Watanabe M, lijima Y, Sugawara D (2017) Paleotsunami history along the northern Japan Trench: evidence from Noda Village, northern Sanriku coast, Japan. Prog Earth Planet Sci 4:42. https://doi. org/10.1186/s40645-017-0158-1

Ishimura D, Miyauchi T (2015) Historical and paleo-tsunami deposits during the last 4000 years and their correlations with historical tsunami events in Koyadori on the Sanriku Coast, northeastern Japan. Prog in Earth and Planet Sci 2:1-18. https://doi.org/10.1186/s40645-015-0047-4

Ishizawa T, Goto K, Yokoyama Y, Miyairi Y (2019) Non-destructive analyses to determine appropriate stratigraphic level for dating of tsunami deposits. Mar Geol 412:19-26. https://doi.org/10.1016/j.margeo.2019.02.009

Ishizawa T, Goto K, Yokoyama Y, Miyairi Y, Sawada C, Nishimura Y, Sugawara D (2017) Sequential radiocarbon measurement of bulk peat for high-precision dating of tsunami deposits. Quat Geochronol 41:202-210. https://doi.org/10.1 016/j.quageo.2017.05.003

Ishizawa T, Goto K, Yokoyama Y, Miyairi Y, Sawada C, Takada K (2018) Reducing the age range of tsunami deposits by $14 \mathrm{C}$ dating of rip-up clasts. Sedi Geol 364:334-341. https://doi.org/10.1016/j.sedgeo.2017.09.008

Jacobs W, Le Hir P, Van Kesteren W, Cann P (2011) Erosion threshold of sandmud mixtures. Contin Shelf Res 31:S14-S25. https://doi.org/10.1016/j.csr.2010.05.012

Jaffe BE, Goto K, Sugawara D, Richmond BM, Fujino S, Nishimura Y (2012) Flow speed estimated by inverse modeling of sandy tsunami deposits: results from the March 112011 tsunami on the coastal plain near the Sendai Airport, Honshu, Japan. Sedi Geol 282:90-109. https://doi.org/10.1016/j. sedgeo.2012.09.002

Jowsey PC (1966) An improved peat sampler. New Phytol 65:245-248. https://doi. org/10.1111/j.1469-8137.1966.tb06356.x

Judd K, Chagué-Goff C, Goff J, Gadd P, Zawadzki A, Fierro D (2017) Multi-proxy evidence for small historical tsunamis leaving little or no sedimentary record. Mar Geol 385:204-215. https://doi.org/10.1016/j.margeo.2017.01.002

Kashima K (1985) Holocene diatom assemblages in Takagami Lowland, central part of Choshi Peninsula, and its relation to changes of sea-level. The Quat Res (Daiyonki-kenkyu) 24:125-138. https://doi.org/10.4116/jaqua.24.125 (in Japanese, with English abstract)

Kashima K, Ota Y, Matsushima Y, Liew P, Sawa M (1990) Holocene sea-level change in Takagami Lowland, the Choshi Peninsula, Japan. The Quat Res (Daiyonki-kenkyu) 29:139-149. https://doi.org/10.4116/jaqua.29.139 (in Japanese, with English abstract)

Kilian MR, van der Plicht J, van Geel B (1995) Dating raised bogs: new aspects of AMS ${ }^{14} \mathrm{C}$ wiggle matching, a reservoir effect and climatic change. Quat Sci Rev 14:959-966. https://doi.org/10.1016/0277-3791(95)00081-X

Kosugi M (1988) Classification of living diatom assemblages as the indicator of environments, and its application to reconstruction of paleoenvironments. The Quat Res (Daiyonki-kenkyu) 27:1-20. https://doi.org/10.4116/jaqua.27.1 (in Japanese, with English abstract)

Kusumoto S, Goto T, Sugai T, Omori T, Satake K (2018) Geological evidence of tsunamis in the past 3800 years at a coastal lowland in the Central Fukushima Prefecture, Japan. Mar Geol 404:137-146. https://doi.org/10.1016/j. margeo.2018.07.004

Matsumoto H, Kumagai M, Yoshida M (2013) Paleotsunami deposit of 2050 years ago and its inundation distance, on the Sendai Coastal Lowland, Northeastern Japan. J Hum Inform 18:79-94 (in Japanese, with English abstract)

Minoura K, Hirano S, Yamada T (2013) Identification and possible recurrence of an oversized tsunami on the Pacific coast of northern Japan. Nat Hazards 68: 631-643. https://doi.org/10.1007/s11069-013-0640-z

Minoura K, Nakaya S (1991) Traces of tsunami preserved in inter-tidal lacustrine and marsh deposits: some examples from northeast Japan. J Geol 99:265287. https://doi.org/10.1086/629488
Moreira S, Costa PJM, Andrade C, Ponte Lira C, Freitas MC, Oliveira MA, Reichart G-J (2017) High resolution geochemical and grain-size analysis of the AD 1755tsunami deposit: insights into the inland extent and inundation phases. Mar Geol 390:94-105. https://doi.org/10.1016/j.margeo.2017.04.007

Nakamura Y, Nishimura Y, Putra PS (2012) Local variation of inundation, sedimentary characteristics, and mineral assemblages of the 2011 Tohoku-oki tsunami on the Misawa coast, Aomori, Japan. Sedi Geol 282:216-227. https:// doi.org/10.1016/j.sedgeo.2012.06.003

Naruse H, Arai K, Matsumoto D, Takahashi H, Yamashita S, Tanaka G, Murayama M (2012) Sedimentary features observed in the tsunami deposits at Rikuzentakata City. Sedi Geol 282:199-215. https://doi.org/10.1016/j.sedgeo.2 012.08.012

Naruse H, Fujino S, Suphawajruksakul A, Jarupongsakul T (2010) Features and formation processes of multiple deposition layers from the 2004 Indian Ocean tsunami at Ban Nam Kem, southern Thailand. Isl Arc 19:399-411. https://doi.org/10.1111/j.1440-1738.2010.00732.x

Ota Y, Matsushima Y, Miyoshi M, Kashima K, Maeda Y, Moriwaki H (1985) Holocene environmental changes in the Choshi Peninsula and its surroundings, easternmost Kanto, central Japan. The Quat Res (Daiyonkikenkyu) 24:13-29. https://doi.org/10.4116/jaqua.24.13 (in Japanese, with English abstract)

Otsubo K, Muraoka K (1988) Critical shear stress of cohesive bottom sediments. J Hydraul Eng 114:1241-1256. https://doi.org/10.1061/(ASCE)0733-9429(1 988)114:10(1241)

Ramírez-Herrera M-T, Lagos M, Hutchinson I, Kostoglodov V, Machain ML, Caballero M, Goguitchaichvili A, Aguilar B, Chagué-Goff C, Goff J, RuizFernández A-C, Ortiz M, Nava H, Bautista F, Lopez Gl, Quintana P (2012) Extreme wave deposits on the Pacific coast of Mexico: tsunamis or storms? - a multi-proxy approach. Geomorphology 139-140:360-371. https://doi. org/10.1016/j.geomorph.2011.11.002

Reimer PJ, Bard E, Bayliss A, Beck JW, Blackwell PG, Ramsey CB, Buck CE, Cheng H, Edwards RL, Friedrich M, Grootes PM, Guilderson TP, Haflidason H, Hajdas I, Hatté C, Heaton TJ, Hoffmann DL, Hogg AG, Hughen KA, Kaiser KF, Kromer B, Manning SW, Niu M, Reimer RW, Richards DA, Scott EM, Southon JR, Staff RA, Turney CSM, van der Plicht J (2013) IntCal13 and Marine13 radiocarbon age calibration curves 0-50,000 years Cal BP. Radiocarbon 55:1869-1887. https:// doi.org/10.2458/azu_js_rc.55.16947

Saino H (2012) Excavated evidence of tsunamis in the Sendai plain. Q Archaeol Stud 58:6-11 (in Japanese)

Sakaguchi Y (1974) Earth science of peat bog-an investigation of an environmental change. University of Tokyo Press, p 329 (in Japanese)

Sawai Y (2012) Study on paleotsunami deposits in geologic stratum. Jour Geol Soc Japan 118:535-558. https://doi.org/10.5575/geosoc.2012.0063 (in Japanese, with English abstract)

Sawai Y (2017) Paleotsunami research along the Pacific coast of Tohoku region. Jour Geol Soc Japan 123:819-830. doi:https://doi.org/10.5575/geosoc.2017. 0055 (in Japanese, with English abstract)

Sawai Y (2020) Subduction zone paleoseismology along the Pacific coast of northeast Japan — progress and remaining problems. Earth Sci Rev 208. https://doi.org/10.1016/j.earscirev.2020.103261 http://www.ncbi.nlm.nih.gov/ pubmed/103261

Sawai Y, Namegaya Y, Okamura Y, Satake K, Shishikura M (2012) Challenges of anticipating the 2011 Tohoku earthquake and tsunami using coastal geology. Geophys Res Lett 39:n/a-n/a. doi:https://doi.org/10.1029/2012GL053692

Sawai Y, Namegaya Y, Tamura T, Nakashima R, Tanigawa K (2015) Shorter intervals between great earthquakes near Sendai: scour ponds and a sand layer attributable to A.D. 1454 overwash. Geophys Res Lett 42:4795-4800. https://doi.org/10.1002/2015GL064167

Schwarz AG, Redmann RE (1988) C4 grasses from the boreal forest region of northwestern Canada. Can J Bot 66:2424-2430. https://doi.org/10.1139/ b88-329

Shinozaki T, Goto K, Fujino S, Sugawara D, Chiba T (2015) Erosion of a paleotsunami record by the 2011 Tohoku-oki tsunami along the southern Sendai Plain. Mar Geol 369:127-136. https://doi.org/10.1016/j.margeo.2015.08.009

Shirai Y, Naruse T (1983) A study of irrigation and conservation of Ponds in Japan—some consideration of pond list in 1981. Geogr Sci 38:20-35. https:// doi.org/10.20630/chirikagaku.38.1_20 (in Japanese)

Simons M, Minson SE, Sladen A, Ortega F, Jiang J, Owen SE, Meng L, Am-Puero JP, Wei S, Chu R, Helmberger DV, Kanamori H, Hetland E, Moore AW, Webb FH (2011) The 2011 magnitude 9.0 Tohoku-Oki earthquake: mosaicking the 
megathrust from seconds to centuries. Science 332:1421-1425. https://doi. org/10.1126/science.1206731

Sudo S (2006) Sand and Beach of Japan (10) Sand and Beach of lioka - Choshi district, Chiba Prefecture, Central Japan. Chishitsu News 625:57-65 (in Japanese)

Sugawara D, Goto K, Imamura F, Matsumoto H, Minoura K (2012) Assessing the magnitude of the 869 Jogan tsunami using sedimentary deposits: prediction and consequence of the 2011 Tohoku-oki tsunami. Sedi Geol 282:14-26. https://doi.org/10.1016/j.sedgeo.2012.08.001

Takada K, Shishikura M, Imai K, Ebina Y, Goto K, Koshiya S, Yamamoto H, Igarashi A, Ichihara T, Kinoshita H, Ikeda T (2016) Distribution and ages of tsunami deposits along the Pacific coast of the Iwate Prefecture River Division Department of Prefectural Land Development, Iwate Prefecture government. Annu Rep Act Fault Paleoearthquake Res 16:1-52 (in Japanese, with English abstract)

Takeda H, Goto K, Goff J, Matsumoto H, Sugawara D (2018) Could tsunami risk be underestimated using core-based reconstructions? Lessons from groundpenetrating radar. Earth Surf Proc Land 43:4. https://doi.org/10.1002/esp.4282

Takeuchi H, Fuji R, Mimura N, Imamura F, Satake K, Tsuji Y, Hochi K, Matsuura K (2007) Survey of run-up height of Empo Boso-oki earthquake tsunami on the coast from Chiba Prefecture to Fukushima Prefecture. Hist Earthq 22:53-59 (in Japanese, with English abstract)

Tanigawa K, Sawai Y, Shishikura M, Fujiwara O, Namegaya Y (2014a) Event deposits on the Pacific coast of Misawa, Aomori Prefecture, northern Japan. The Quat Res (Daiyonki-kenkyu) 53:55-62. https://doi.org/10.4116/jaqua.53.55 (in Japanese)

Tanigawa K, Sawai Y, Shishikura M, Namegaya Y, Matsumoto D (2014b) Geological evidence for an unusually large tsunami on the Pacific coast of Aomori, Northern Japan. J Quaternary Sci 29:200-208. https://doi.org/10.1 002/jas. 2690

Toda S (2012) Long-term earthquake forecasting associated with the 2011 off the Pacific coast of Tohoku earthquake. Jpn J Multiphase Flow 26:4-10. doi: https://doi.org/10.3811/jjmf.26.4 (in Japanese, with English abstract)

Toda S, Lin J, Stein RS (2011) Using the 2011 MW 9.0 off the Pacific coast of Tohoku earthquake to test the Coulomb stress triggering hypothesis and to calculate faults brought closer to failure. Earth Planets Space 63:725-730. https://doi.org/10.5047/eps.2011.05.010

Tsuji Y, Yanuma T, Hirahata T, Imamura F (2012) Field survey of inundation height of Enpo Boso earthquake tsunami (1677) in Boso Peninsula. Chiba Prefecture. Rep tsunami. J Eng Res 29:209-223 (in Japanese)

Tuukkanen T, Marttila H, Kløve B (2014) Effect of soil properties on peat erosion and suspended sediment delivery in drained peatlands. Water Resour Res 50: 3523-3535. https://doi.org/10.1002/2013WR015206

Watanabe T, Hosoda N, Tsuchiya N, Nakamura T, Hirano N, Okamoto A, Nara FW, Tohoku University Tsunami Sediment Research Group (2014) radiocarbon dating historical tsunami deposits from the Sendai plain, Northeastern Japan: preliminary age model of HS Continuous Soil sediment series. J Geogr 123: 904-922. doi:https://doi.org/10.5026/jgeography.123.904 (in Japanese, with English abstract)

Watanabe T, Matsunaka T, Nakamura T, Nishimura M, Izutsu Y, Minami M, Nara FW, Kakegawa T, Wang J, Zhu L (2010) Last Glacial-Holocene geochronology of sediment cores from a high-altitude Tibetan lake based on AMS ${ }^{14} \mathrm{C}$ dating of plant fossils: implications for paleoenvironmental reconstructions. Chem Geol 277:21-29. https://doi.org/10.1016/j.chemgeo.2010.07.004

Wedepohl KH (1971) Environmental influences on the chemical composition of shales and clays. Phys Chem Earth 8:307-333. https://doi.org/10.1016/0079-1 946(71)90020-6

Williams S, Prasetya G, Chagué-Goff C, Goff J, Cheung KF, Davies T, Wilson T (2011) Characterising diagnostic proxies for identifying paleotsunamis in a tropical climatic regime, Samoan Islands Proceedings of the MTS/IEEE Oceans 2011 Conference, KONA, Hawaii 19-22. doi:https://doi.org/10.23919/ OCEANS.2011.6107137

Yanagisawa H, Goto K, Sugawara D, Kanamaru K, Iwamoto N, Takamori Y (2016) Tsunami earthquake can occur elsewhere along the Japan Trench-historical and geological evidence for the 1677 earthquake and tsunami. J Geophys Res Solid Earth 121:3504-3516. https://doi.org/10.1002/2015JB012617

\section{Publisher's Note}

Springer Nature remains neutral with regard to jurisdictional claims in published maps and institutional affiliations.

\section{Submit your manuscript to a SpringerOpen ${ }^{\circ}$ journal and benefit from:}

- Convenient online submission

- Rigorous peer review

- Open access: articles freely available online

- High visibility within the field

- Retaining the copyright to your article

Submit your next manuscript at $\boldsymbol{\nabla}$ springeropen.com 